\title{
Systematics, speciation and biogeography of the dwarf chameleons (Brookesia; Reptilia, Squamata, Chamaeleontidae) of northern Madagascar
}

\author{
C. J. Raxworthy and R. A. Nussbaum \\ Division of Herpetology, Museum of Zoology, University of Michigan, Ann Arbor, Michigan, \\ 48109, USA
}

(Accepted 15 February 1994)

(With 5 plates and 7 figures in the text)

\begin{abstract}
Brookesia dwarf chameleons, endemic to Madagascar, were surveyed at the following localities in northern Madagascar (north of $16^{\circ} \mathrm{S}$ ): Montagne d'Ambre, Ankarana, Manongarivo, Tsaratanana, Marojejy and Masoala. A total of 15 species occur in this region. Six new species are described and five new synonyms are identified. The genus Brookesia, the most speciose chamaeleontid genus in Madagascar, contains 23 species.

Almost all the northern Brookesia species are restricted to rainforest and occupy a relatively narrow elevational range. Although the northern rainforests represent just one-third of the total rainforest and about $5 \%$ of the total island area, $65 \%$ of the Brookesia species occur in this region, and $52 \%$ are endemic to the northern rainforest. Five new biogeographic regions of the northern rainforest are identified based on centres of Brookesia endemicity: Montagne d'Ambre, Northwest, Tsaratanana, Northeast and East. Speciation is thought to have been facilitated in the north through geographic isolation, with the Tsaratanana mountain range and the dry forests south of Montagne d'Ambre forming barriers to dispersal, and the Tsaratanana mountains acting as a centre of isolation. The fragmented distribution of several Brookesia species of low altitude rainforest suggests a period in Madagascar's history when the climate was wetter and low altitude rainforest much more widespread.
\end{abstract}

\section{Contents}

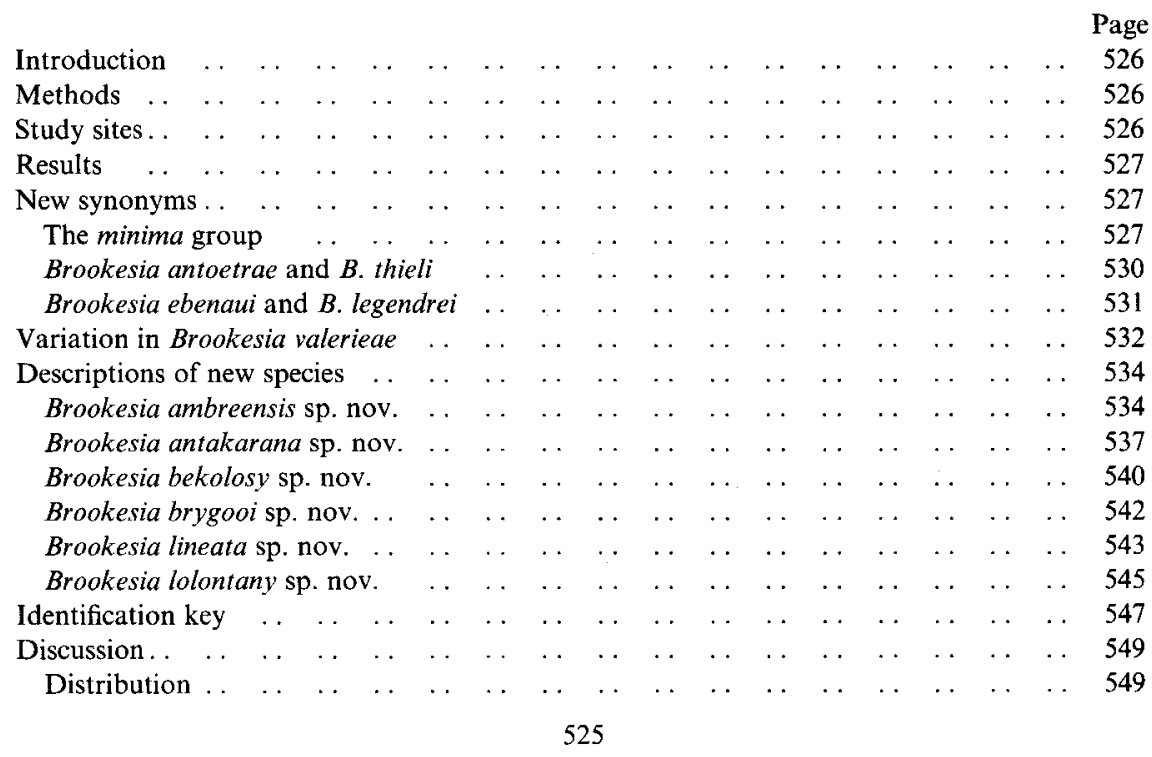




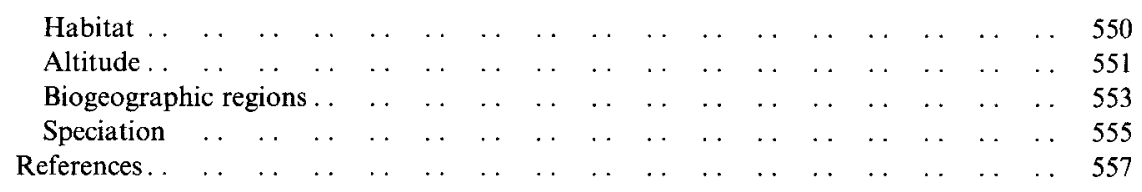

\section{Introduction}

The genus Brookesia was described by Gray (1865) with the type species Brookesia superciliaris (Kuhl, 1820). The genus is now considered to be endemic to Madagascar, being differentiated from the African dwarf chameleons Rhampholeon Günther 1874 by hemipenis characters. The hemipenis apex has crests in Brookesia and horns in Rhampholeon (Klaver \& Böhme, 1986). The most recent revision of the genus Brookesia included 19 species (Brygoo, 1978), and three more species have since been described (Ramanantsoa, 1979; Raxworthy, 1991). Compared to the two other Malagasy chameleon genera: Calumma Gray, 1865 and Furcifer Fitzinger, 1843, the genus Brookesia is the most speciose, representing one of the largest reptilian radiations in Madagascar (second only to the scincid genus Amphiglossus). Brookesia is a poorly studied genus, with 11 species known only from their type localities.

Between 1988 and 1993, we surveyed the herpetofauna of the rainforests of northern Madagascar. The results of this study with regard to Brookesia are provided here, along with a systematic revision of the genus and a new identification key. The biogeography of Brookesia is discussed in relation to the complex northern region of Madagascar.

\section{Methods}

Brookesia were collected by searching low vegetation and the forest floor during day and night searches. The majority of specimens were found roosting at night (see Raxworthy, 1991). A single specimen was caught in a pitfall trap with drift fence. Photographs of representative specimens were taken soon after capture to record natural coloration.

All measurements were made on preserved specimens. Measurements were made to the nearest mm using a ruler, or to the nearest $0.1 \mathrm{~mm}$ using a graticule and binocular microscope. Snout-vent length is abbreviated to SVL. The dorsolateral pointed tubercles on the body are numbered, with the most anterior pair being the 1st. The total number of pairs includes the most posterior pair in the sacral region, which is frequently mounted on a lateral projection of the body. Head crests and ornamentation nomenclature follows Raxworthy (1991), which is based on Brygoo (1978), with the exception that the body spines are referred to here as pointed tubercles. The following museum abbreviations are used: BM, British Museum (Natural History); MNHP, Muséum National d'Histoire Naturelle, Paris; UMMZ, University of Michigan, Museum of Zoology.

\section{Study sites}

Fifteen sites were surveyed within seven major localities. All these sites are north of latitude $16^{\circ} \mathrm{S}$, which defines northern Madagascar. The seven survey localities and all other historical collecting sites of Brookesia are shown in Fig. 1. The coordinates, local habitat type and altitudinal range of each survey site are given in Table I. 
TABLE I

Survey sites in northern Madagascar which yielded Brookesia

\begin{tabular}{|c|c|c|c|c|}
\hline Locality & Site (site number) & Coordinates & Altitude (m) & Habitat \\
\hline \multirow[t]{2}{*}{ M. d'Ambre } & Antomboka River (1) & $12^{\circ} 32^{\prime} \mathrm{S}, 49^{\circ} 10^{\prime} \mathrm{E}$ & $900-1450$ & rainforest \\
\hline & Antomboka River Fitsahana (2) & $12^{\circ} 29^{\prime} \mathrm{S}, 49^{\circ} 10^{\prime} \mathrm{E}$ & $600-950$ & rainforest \\
\hline Ankarana & Amposatelo (3) & $12^{\circ} 56^{\prime} \mathrm{S}, 49^{\circ} 01^{\prime} \mathrm{E}$ & $50-200$ & dry forest \\
\hline Nosy Be & Ampasindava, Lokobe (4) & $13^{\circ} 25^{\prime} \mathrm{S}, 48^{\circ} 19^{\prime} \mathrm{E}$ & $0-430$ & rainforest \\
\hline \multirow{4}{*}{ Manongarivo } & Manongarivo River (5) & $13^{\circ} 59^{\prime} \mathrm{S}, 48^{\circ} 17^{\prime} \mathrm{E}$ & 150 & rainforest \\
\hline & Ambalafary Village (6) & $14^{\circ} 04^{\prime} \mathrm{S}, 48^{\circ} 17^{\prime} \mathrm{E}$ & $50-350$ & rainforest \\
\hline & Antsahabe River (7) & $14^{\circ} 05^{\prime} \mathrm{S}, 48^{\circ} 21^{\prime} \mathrm{E}$ & $600-800$ & rainforest \\
\hline & Bekolosy (8) & $14^{\circ} 02^{\prime} \mathrm{S}, 48^{\circ} 18^{\prime} \mathrm{E}$ & $1100-1200$ & rainforest \\
\hline \multirow[t]{2}{*}{ Tsaratanana } & Matsabory Lake (9) & $14^{\circ} 09^{\prime} \mathrm{S}, 48^{\circ} 58^{\prime} \mathrm{E}$ & $2050-2100$ & rainforest \\
\hline & Befosa River (10) & $14^{\circ} 11^{\prime} \mathrm{S}, 48^{\circ} 57^{\prime} \mathrm{E}$ & 1600 & rainforest \\
\hline \multirow[t]{2}{*}{ Marojejy } & Manantenina River (11) & $14^{\circ} 26^{\prime} \mathrm{S}, 49^{\circ} 47^{\prime} \mathrm{E}$ & $200-800$ & rainforest \\
\hline & Marojejy Mountain (12) & $14^{\circ} 26^{\prime} \mathrm{S}, 49^{\circ} 45^{\prime} \mathrm{E}$ & $1250-1350$ & rainforest \\
\hline \multirow[t]{3}{*}{ Masoala } & Ambato Mountain (13) & $15^{\circ} 16^{\prime} \mathrm{S}, 50^{\circ} 20^{\prime} \mathrm{E}$ & $150-200$ & rainforest \\
\hline & Ankavanana River (14) & $15^{\circ} 19^{\prime} \mathrm{S}, 50^{\circ} 14^{\prime} \mathrm{E}$ & $80-400$ & rainforest \\
\hline & Andranobe River (15) & $15^{\circ} 41^{\prime} \mathrm{S}, 49^{\circ} 58^{\prime} \mathrm{E}$ & $0-80$ & rainforest \\
\hline
\end{tabular}

\section{Results}

Thirteen species were recorded at the 15 study sites. The distribution of each species sampled is given in Table II. The maximum number of species for a locality was six (Manongarivo) and the minimum was two (Tsaratanana). Five species were undescribed. Two species known only from their type localities, Brookesia betschi and B. valerieae, were collected at new sites, with other range extensions made for another four species.

Comparative studies made during the course of describing the new collection led to the recognition of five new synonyms, and another new species from the arid regions of southwestern Madagascar. New specimens of Brookesia valerieae, a species previously represented by a female holotype only, allow us to describe morphological variation and the structure of the hemipenis of this species.

\section{New synonyms}

\section{The minima group}

The smallest species of Brookesia are members of the minima group as recognized by Brygoo (1978), which contains five species. Brookesia minima was described by Boettger (1893) from three specimens collected from Nosy Be. Mocquard $(1894,1900)$ described two more species, Brookesia tuberculata from Montagne d'Ambre and $B$. dentata from Suberbieville. Brookesia tuberculata is diagnosed by the many irregularly positioned enlarged tubercles on the lateral surfaces of the body, that are fewer and arranged in 3-4 longitudinal lines in $B$. minima (Mocquard, 1909). Brookesia dentata is diagnosed by the two dorsolateral pointed tubercles on the anterior half of the body which are absent in B. minima and B. tuberculata (although both species may have small rounded dorsolateral tubercles). More recently, Brookesia peyrierasi and B. ramanantsoai were described by Brygoo \& Domergue (1975). Brookesia ramanantsoai is so similar to $B$. dentata that the authors were unable to give diagnostic characters to separate the two species (they described the hemipenis of Brookesia ramanantsoai, but the hemipenis of 
$B$. dentata remains unknown). Similarly, using external morphological characters, Brookesia peyrierasi could not be distinguished from B. minima. Brygoo \& Domergue (1970) described the hemipenis of Brookesia peyrierasi but the hemipenis structure of B. minima is unknown. The absence of diagnostic characters forced Brygoo (1978) to use geographic locality to separate all the minima group species (except Brookesia dentata) in his identification key. Although Brygoo \& Domergue (1975) clearly expected that diagnostic differences in hemipenis structure would eventually be found to differentiate Brookesia peyrierasi from $B$. minima, and differentiate $B$. ramanantsoai from $B$. dentata, it is surprising that $B$. peyrierasi and $B$. ramanantsoai were described in the absence of such data.

The hemipenis of Brookesia tuberculata from Montagne d'Ambre has a single apex bearing three short horns (Brygoo \& Domergue, 1975), while the hemipenis of $B$. peyrierasi from Nosy Mangabe and Fantanendra (north of Maroantsetra) has a bi-lobed apex each bearing a papillate crest of 4-6 papillae (Brygoo \& Domergue, 1970). The affinities of both these species with Brookesia minima remains unknown. Klaver \& Böhme (1986) did not consider the hemipenis description of Brookesia tuberculata (and also B. ramanantsoai) to be complete because the

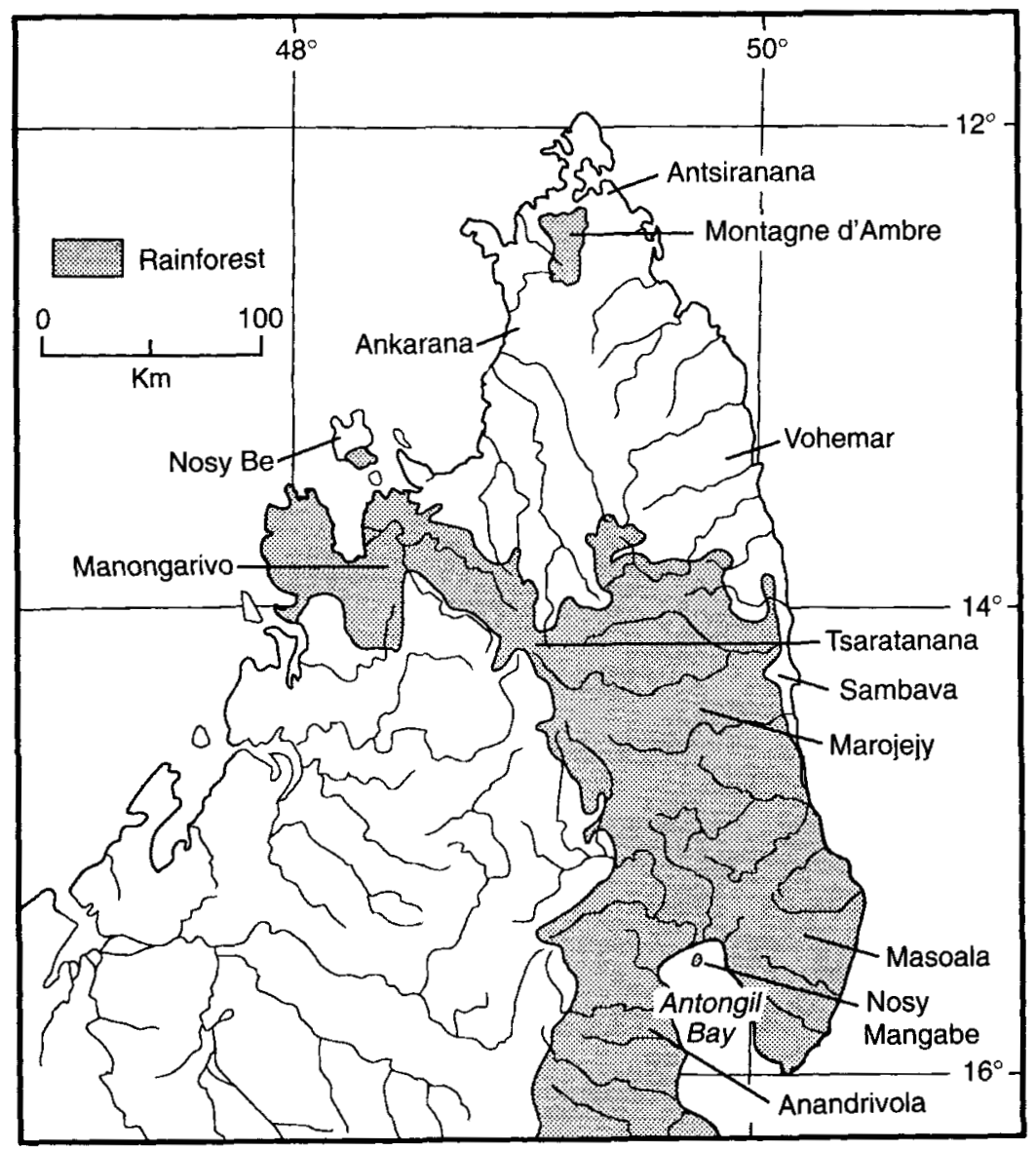

FIG. 1. Brookesia collecting sites in northern Madagascar. 


\begin{tabular}{|c|c|c|c|c|c|c|c|c|c|c|c|c|c|c|c|}
\hline \multirow[b]{3}{*}{ SPECIES } & \multicolumn{15}{|c|}{ SITE NUMBER } \\
\hline & \multicolumn{2}{|c|}{ Ambre } & \multicolumn{3}{|c|}{ Ankar N. Be } & \multicolumn{3}{|c|}{ Manongarivo } & \multicolumn{2}{|c|}{ Tsaratan. } & \multicolumn{2}{|c|}{ Marojejy } & \multicolumn{3}{|c|}{ Masoala } \\
\hline & 1 & 2 & 3 & 4 & 5 & 6 & 7 & 8 & 9 & 10 & 11 & 12 & 13 & 14 & 15 \\
\hline Brookesia ambreensis sp. nov. & $*$ & & & & & & & & & & & & & & \\
\hline B. antakarana sp. nov. & $*$ & & & & & & & & & & & & & & \\
\hline $\begin{array}{l}\text { B. bekolosy sp. nov. } \\
B \text {. betschi }\end{array}$ & & & & & & & & * & & & & * & & & \\
\hline $\begin{array}{l}\text { B. betschl } \\
\text { B. griveaudi }\end{array}$ & & & & & & & & & & $*$ & * & & $*$ & * & \\
\hline B. karchei & & & & & & & & & & & * & & & & \\
\hline B. ebenaui & & * & & $*$ & * & & & & & & & & & & \\
\hline B. lineata sp. nov. & & & & & & & & * & & & & & & & \\
\hline B. lolontany sp. nov. & & & & & & & & & $*$ & $*$ & & & & & \\
\hline B. minima & & * & & $*$ & * & * & & & & & * & & * & & \\
\hline B. stumpffi & & $*$ & $*$ & $*$ & * & $*$ & * & & & & & & & & \\
\hline B. superciliaris & & & & & & & & & & & & & & & $*$ \\
\hline B. valerieae & & & & & & $*$ & $*$ & & & & & & & & \\
\hline
\end{tabular}

descriptions do not include differentiated apical ornamentation, possibly, they suggest, due to seasonal variation.

Three minima group species were reported by Brygoo (1978) from northern Madagascar: Brookesia minima, B. tuberculata and B. peyrierasi. We collected the following minima group specimens from northern Madagascar: Montagne d'Ambre, UMMZ 203623-7; Nosy Be, UMMZ 203924-32; Manongarivo, UMMZ 203613-4; Marojejy, UMMZ 203615-21; and Masoala, UMMZ 203622. An examination of the external morphology of these specimens, and the type material of Brookesia tuberculata (MHNP 1893.183) and B. peyrierasi (MHNP 1968.184, 1968.186-191) and other specimens from Montagne d'Ambre (MHNP 1986.870-2), Nosy Be (MHNP 1884.582, 1886.25), Marojejy (MHNP 1986.876-9), Sambava (MHNP 1974.251-2), and Nosy Mangabe (MHNP 1974.236-50, 1989.3748) using characters described by Brygoo \& Domergue $(1970,1975)$, did not reveal any characters that could diagnose these different species. The arrangement of enlarged tubercles on the lateral surface of the body, the numbers of rounded dorsolateral tubercles on the body and the presence or absence of a chevron pattern on the vertebral line are all variable within populations, and no consistent differences in head lengths were found among populations. Three specimens (from Marojejy and Masoala), UMMZ 203617-8 and 203622, had fully everted hemipenes with a bi-lobed apex, each lobe bearing a papillate crest of 3-4 papiliae, similar to the condition in Brookesia peyrierasi. The hemipenes of specimens from Montagne d'Ambre, Nosy Be, and Manongarivo were not fully everted. The hemipenes of the Brookesia tuberculata specimens MHNP 1986.871-2 (tags not attached) are filled with a solid black material suggesting they were everted using wax. The hemipenes are now badly deformed and do not appear to be fully everted.

We conclude that there is no evidence to diagnose more than one minima group Brookesia in northern Madagascar, therefore, based on priority, we consider this widespread northern species to be Brookesia minima and synonymize both Brookesia tuberculata and B. peyrierasi within this species.

We also examined the types of Brookesia ramanantsoai (MHNP 1973.1401-3) and B. dentata (MHNP 1899.322) and two additional specimens: MHNP 1968.139 (previously a paratype of 
B. thieli), collected at Perinet by J. Thiel; and UMMZ 196241, collected in Mantady National Park, $18^{\circ} 51^{\prime} \mathrm{S}, 48^{\circ} 28^{\prime} \mathrm{E}$, Moramanga Fivondronana, Toamasina Province, Madagascar, by J.B. Ramanamanjato, A. Raselimanana and C.J. Raxworthy. The hemipenes of MHNP 1973.1401 have been filled with a black material (like MHNP 1986.871-2) and have ruptured making it impossible to see the original structure. All six specimens are very similar and are characterized by two enlarged, dorsolateral, pointed tubercles on the anterior half of the body, which are not found in Brookesia minima. We therefore consider this group to represent a single species and view Brookesia ramanantsoai as a junior synonym of $B$. dentata. The Brookesia dentata holotype was collected from the "Environs de Suberbieville, Boina" by Grandidier between 1898-99. Suberbieville was a gold mine just south of Maevatanana (Keller, 1901) in the Boina region (Northwest). Native forest in this region is dry deciduous forest typical of the west. All other specimens have been collected in rainforest in the east.

\section{Brookesia antoetrae and $B$. thieli}

Brookesia thieli was described by Brygoo \& Domergue (1969), based on eight types (four males, three females, one juvenile) collected in the East: the holotype from Ambodimanga, and the paratypes from Ambodimanga, Perinet and Fierenana. Two years later, Brygoo \& Domergue (1971) described Brookesia antoetrae based on three specimens (two of unknown sex and a gravid female) collected in the East: the holotype from Ambahona (Antoetra) and the paratypes from Ambahona and Ankarampotsy (although Brygoo, 1978; listed only the paratype from Ambahona).

The descriptions of Brookesia thieli and B. antoetrae are very similar. Brygoo \& Domergue (1971) provided only one character to separate the two species, which is the size of the dorsolateral pointed tubercles of the body. Brygoo (1978) later defined this character more precisely: dorsolateral pointed tubercles of Brookesia antoetrae less than $1 \mathrm{~mm}$ in length and those of B. thieli $1 \mathrm{~mm}$ or more in length. In his Brookesia key, Brygoo (1978) used another character to separate these two species: the presence $(B$. thieli) or absence $(B$. antoetrae) of ossified pointed tubercles on the tail. The holotype of Brookesia thieli was described and illustrated as having 14 pairs of dorsolateral pointed tubercles on the tail, all of which are smaller than the tubercles of the body (Brygoo \& Domergue, 1969).

We examined the type material of Brookesia thieli and B. antoetrae, as well as other specimens belonging to these two species which are in the Paris Museum (listed by Brygoo, 1978) and three specimens at UMMZ: 196216, collected 7 February 1991 at Vatoharanana, Ranomafana National Park, $21^{\circ} 17^{\prime} \mathrm{S}, 47^{\circ} 26^{\prime} \mathrm{E}$, Ifanadiana Fivondronana, Fianarantsoa Province, Madagascar, by C.J. Raxworthy; 196217-8 collected 5 and 11 April 1991 at Mantady National Park, $18^{\circ} 51^{\prime} \mathrm{S}$, 48 $28^{\prime} \mathrm{E}$, Moramanga Fivondronana, Toamasina Province, Madagascar, by J.B. Ramanamanjato, A. Raselimanana and C.J. Raxworthy.

One of the paratypes of Brookesia thieli, MHNP 1968.139, reported to be a juvenile, is actually an adult male $B$. dentata. All the other examined specimens have a series of dorsolateral pointed tubercles of variable size on the tail. The holotype of Brookesia antoetrae has larger pointed tail tubercles than the paratype (1968.134) of $B$. thieli. The length of the pointed body tubercles is less than $1 \mathrm{~mm}$ in the paratypes (1968.135 and 1968.137) of Brookesia thieli. We conclude that the length of the dorsolateral pointed body tubercles and the presence of pointed tail tubercles do not separate Brookesia antoetrae from B. thieli, and therefore consider B. antoetrae to be a junior synonym of $B$. thieli. 


\section{Brookesia ebenaui and $B$. legendrei}

Boettger (1880) briefly described (in latin) Brookesia ebenaui and the following year (Boettger, 1881) described in more detail and illustrated the single female holotype, collected from Nosy Be. His diagnostic characters included: enlarged supranasal cone, which was $1 \mathrm{~mm}$ in length, large dorsolateral body spines; longitudinal series of tail spines, similar in size to those of the body; and square cross-section of the tail; Boettger's (1881) description was published again, almost verbatim by Werner (1902), along with an illustration (plate 22) of the holotype held at the Senckenberg Museum. Werner noted that Brookesia ebenaui did not have the pelvic shield in the sacral region that is present in $B$. stumpffi. He also reported that two other specimens existed in the Paris and British Museums, collected from Montagne d'Ambre and Diégo-Suarez. Mocquard's (1909) key to the Madagascar Brookesia, identified B. ebenaui by the series of spines on each side of the vertebral line, that continue on to the tail, and the large supranasal cone above each nostril.

Angel's (1942) key to the Brookesia species gave the following characters for Brookesia ebenaui: body not keeled, digits undersurfaces spiny; dorsolateral series of body spines, that more or less continue on to the tail, and a prominent supranasal cone. Unlike Boettger, he considered this species to have a pelvic shield in the sacral region, and gave the following new localities: Fito, Sihanaka, Angavo, Manjakandriana, Tananarive, Ste. Marie de Marovoay, Ankarampotsy, Ikongo. Brygoo (1978) noted that many of these localities are errors due to misidentifications, such as Ankarampotsy (Brookesia antoetrae) and Fito (B. lambertoni).

Brygoo \& Domergue (1971) described the hemipenis of two Brookesia collected from Kasijy (150 km south of Mitsingy, West Madagascar). They found hemipenal differences between the Kasijy specimens and Brookesia stumpffi collected from l'Ankara de Diégo. Although they initially considered the Kasijy males to be Brookesia stumpffi, the differences in hemipenis structure convinced them the Kasijy specimens were different, and they assigned them to $B$. ebenaui. No other characters were provided to justify this decision.

Brygoo (1978) completely redescribed Brookesia ebenaui based on Paris Museum specimens collected at Analavelona, Kasijy ( $50 \mathrm{~km}$ north of Toliara), Bemaraha Reserve (Réserve Naturelle Intégrale No. 9) and Antsalova; and a British Museum specimen collected at Sakaraha. All these specimens were taken in arid habitats of the West and Southwest, whereas the Brookesia ebenaui holotype was collected in either rainforest or secondary vegetation on Nosy Be. Brygoo (1978) noted that the widespread distribution of Brookesia ebenaui was unusual, but considered this to be genuine. Remarkably, Brygoo \& Domergue (1971) and Brygoo (1978) did not examine Brookesia ebenaui material from the type locality or from other sites in northern Madagascar, and ignored obvious differences between the holotype of B. ebenaui and their new material from the West and Southwest.

The main characters of Brygoo's (1978) Brookesia ebenaui from the West and Southwest are: pelvic shield in the sacral area; tail with or without a few, small, dorsolateral pointed tubercles; and a prominent lateroventral pointed tubercle on the tailbase posterior to the cloaca. These characters are very different from the holotype of Brookesia ebenaui (which lacks a pelvic shield, has prominent dorsolateral tail spines and lacks the lateroventral pointed tubercle posterior to the cloaca). The Brookesia ebenaui specimens from the West and Southwest are most similar to $B$. decaryi and $B$. bonsi, but differ in head ornamentation. We therefore consider "Brookesia ebenaui" from the West and Southwest to be a new species which we describe below.

Brookesia legendre $i$ was described by Ramanantsoa (1979) based on five specimens collected at 
Nosy Be (the type locality of $B$. ebenaui). The characters of Brookesia legendrei are: strongly developed supranasal cone, series of dorsolateral pointed tubercles on body, series of dorsolateral spines on tail, absence of a pelvic shield in sacral area, absence of a lateroventral pointed tubercle on tailbase posterior to the cloaca. These characters are all shared by the holotype of Brookesia ebenaui. It appears that Ramanantsoa did not recognize the similarity between Brookesia ebenaui and $B$. legendrei because he was misled by the detailed but erroneous new description of B. ebenaui given by Brygoo (1978).

We tried unsuccessfully to borrow the holotype of Brookesia ebenaui. However, the detailed description and head illustration given by Boettger (1881), and the very fine complete holotype illustration given by Werner (1902), leave us in no doubt that Brookesia legendrei is a junior synonym of Brookesia ebenaui. We recently collected Brookesia ebenaui at Montagne d'Ambre which is one of the first localities where B. ebenaui was collected after the holotype was described.

\section{Variation in Brookesia valerieae}

The original description of this species by Raxworthy (1991) is based on a single female collected at Manongarivo in 1988. Since then we collected seven more specimens (three males, four females) from Manongarivo. All the specimens were taken from Antsahabe River, Manongarivo Special Reserve, $14^{\circ} 05^{\prime} \mathrm{S}, 48^{\circ} 21^{\prime} \mathrm{E}$, Ambanja Fivondronana, Antsiranana (Diégo Suarez) Province, Madagascar, by J.B. Ramanamanjato, A. Raselimanana and C.J. Raxworthy. They were all captured at night roosting on vegetation in primary rainforest. The specific circumstances of capture are as follows: UMMZ 201448, collected 28 February 1992 at $550 \mathrm{~m}$ altitude; UMMZ 201449-51, collected 29 February 1992 at 650-700 m altitude; UMMZ 201452 collected 1 March 1992 at $650 \mathrm{~m}$ altitude; UMMZ 201453 collected 2 March 1992 at $680 \mathrm{~m}$ altitude; UMMZ 203628 collected 29 February 1992 at $650-700 \mathrm{~m}$ altitude.

The holotype (BM 1988.8) was collected in primary rainforest, $7 \mathrm{~km} \mathrm{NW}$ of the Antsahabe River where the new material was collected. Raxworthy (1991) reported that the holotype was collected at $350 \mathrm{~m}$ elevation, but a return visit to the collecting site proved the actual elevation is $500 \mathrm{~m}$. The known altitudinal range, therefore, of Brookesia valerieae is $500-700 \mathrm{~m}$. Because we did not see Brookesia valerieae at lower or higher elevations within Manongarivo, we think this is an accurate estimate of the altitudinal range for this species. Brookesia valerieae was not found at Montagne d'Ambre and Ankarana, and appears to be restricted to the Northwest rainforest.

The following morphological variation was found in the examined material, including the holotype. The number of dorsolateral pointed tubercles varies between nine and ten, including the enlarged, backward pointing, posteriormost pair: BM 1988.8 and UMMZ 201449 with nine, all others with ten. Specimens with ten dorsolateral pointed tubercles have equal spacing between the first eight anterior pairs. The arrangement of nine dorsolateral pointed tubercles is due to the absence of the 8th tubercle. The tails of the new specimens have a faint dorsolateral line of pointed small tubercles from the tail base to near the tail tip. This was most obvious for UMMZ 201450, for which 14 tubercles could be seen; for the other specimens, the tubercles are fewer and less obvious.

The colour in preservative varies as follows: no elongated forward pointing chevrons could be seen between the dorsolateral pointed tubercles in the mid-body regions of UMMZ 201448-9, 201451, 201453 and 203628; a pale brown vertebral line could be seen on the body from the 1st to the 8th pair of dorsolateral pointed tubercles of UMMZ 210450-1.

The hemipenis of Brookesia valerieae (UMMZ 210452) is clavate and asymmetrical, bearing an 

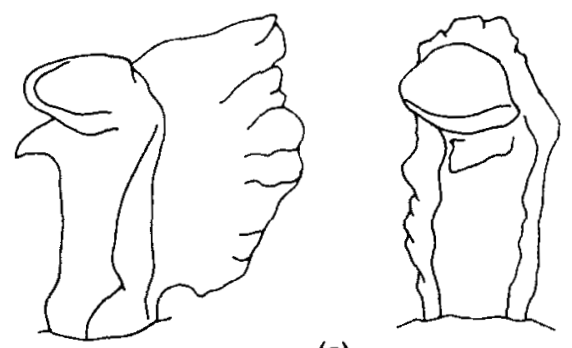

(a)

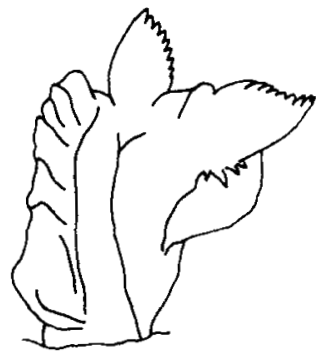

(b)
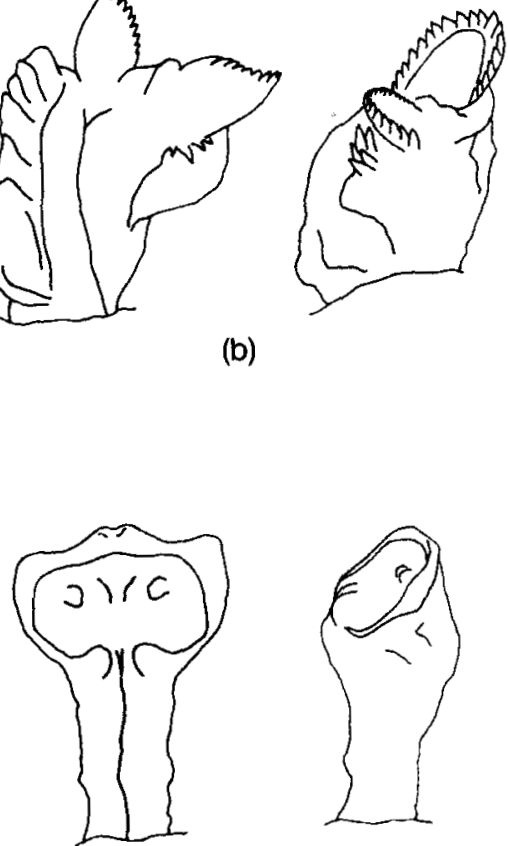

(d)

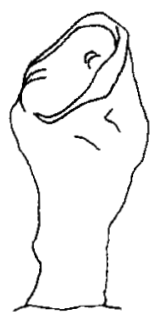

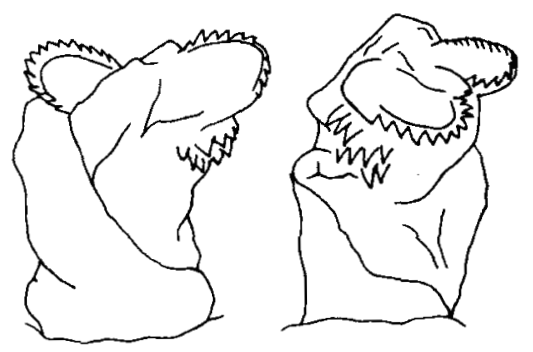

(c)
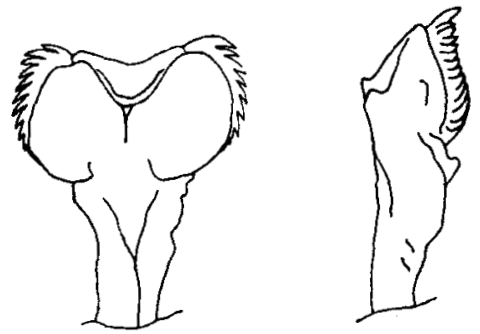

(e)

FIG. 2. Sulcal and lateral views of (a) left hemipenis of Brookesia valerieae, UMMZ 201452; (b) right hemipenis of Brookesia ambreensis sp. nov., UMMZ 203635 (holotype); (c) right hemipenis of Brookesia antakarana sp. nov., UMMZ 200071 (holotype); (d) left hemipenis of Brookesia bekolosy sp. nov., UMMZ 200078 (holotype); (e) left hemipenis of Brookesia lineata sp. nov., UMMZ 200073 (holotype).

apex with a single, large, disc-like lobe that is devoid of papillae and not denticulated (Fig. 2). Below this lobe there is a small, blunt, lateral projection. On the opposite side of the lateral projection, attached to the entire length of the truncus and apex, there is a very broad, flattened, blade-like structure with a slightly crenulate border.

The diagnosis for Brookesia valerieae is accordingly modified: a Brookesia with a complete series of nine or ten dorsolateral pointed tubercles on the body; the seven anterior pointed 
tubercles (1st-7th) equal in size and spacing, and they project perpendicularly to the body; the most posterior ( 9 th or 10th) pointed tubercle pointing backward slightly on a pointed lateral projection of the body; no well-defined dorsal pelvic shield in the sacral region; no dorsal ridge (keel), no pointed tubercles around the cloaca; supraocular cone pointed and does not project further forward than nostril; dorsal region of body sometimes with three elongated dark chevrons or a pale vertebral line; SVL $46-53 \mathrm{~mm}$.

\section{Descriptions of new species}

\section{Brookesia ambreensis sp. nov.}

Holotype-UMMZ 203635, mature male, collected 8 January 1992, Antomboka River, Montagne D’Ambre National Park, $12^{\circ} 29^{\prime} \mathrm{S}, 49^{\circ} 10^{\prime} \mathrm{E}, 670 \mathrm{~m}$ altitude, Antsiranana Fivondronana, Antsiranana (Diégo Suarez) Province, Madagascar, by J.B. Ramanamanjato, A. Raselimanana and C.J. Raxworthy.

Paratypes-UMMZ 200074-76, male, female and female, collected 18, 24 and 30 November 1991, Antomboka River, Montagne d'Ambre National Park, $12^{\circ} 32^{\prime} \mathrm{S}, 49^{\circ} 10^{\prime} \mathrm{E}, 1050-1100 \mathrm{~m}$ altitude, Antisiranana Fivondronana, Antisiranana (Diégo Suarez) Province, Madagascar, by J.B. Ramanamanjato, A. Raselimanana and C.J. Raxworthy; UMMZ 200077, male, collected 23 December 1991, Antomboka River Fitsahana, Montagne D'Ambre National Park, 12²9'S, $49^{\circ} 10^{\prime} \mathrm{E}, 650 \mathrm{~m}$ altitude, Antsiranana Fivondronana, Antsiranana (Diégo Suarez) Province, Madagascar, by J.B. Ramanamanjato, A. Raselimanana and C.J. Raxworthy; UMMZ 203631, male. collected 4 December 1991, Antomboka River, Montagne d'Ambre National

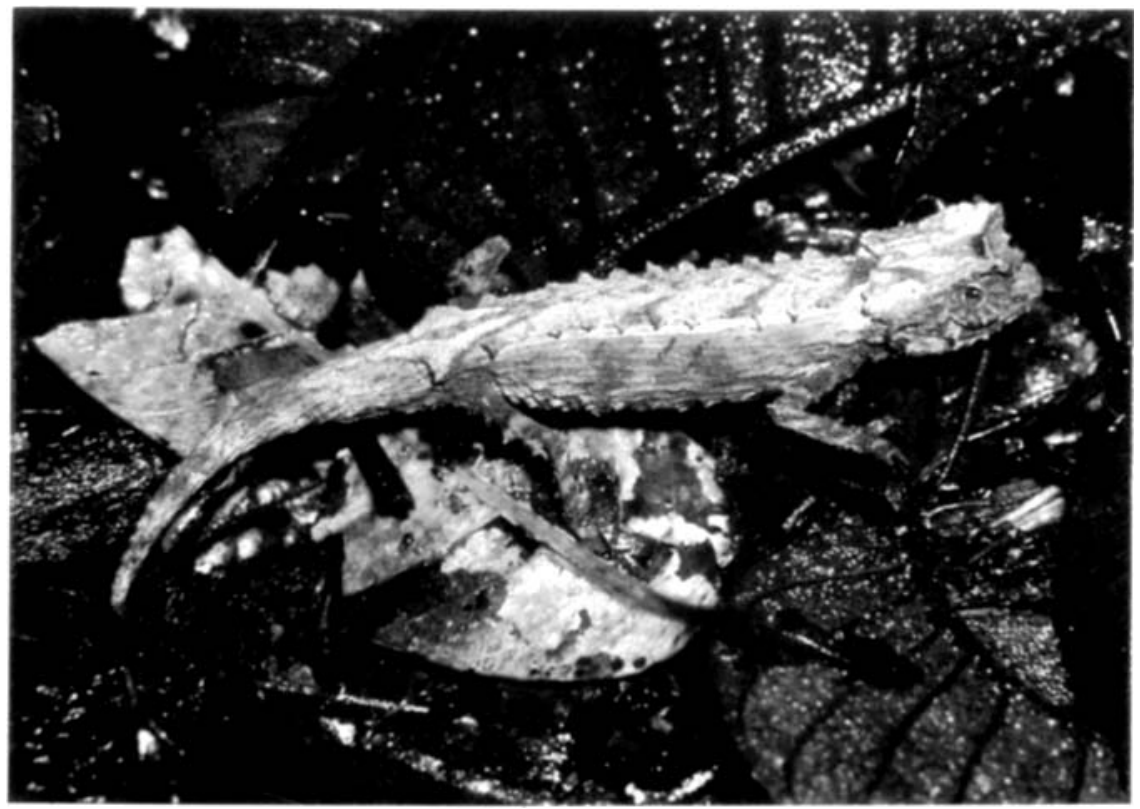

Plate I. Brookesia ambreensis sp. nov., UMMZ 200077 (paratype). 
Park, $12^{\circ} 32^{\prime} \mathrm{S}, 49^{\circ} 10^{\prime} \mathrm{E}, 1150 \mathrm{~m}$ altitude, Antsiranana Fivondronana, Antsiranana (Diégo Suarez) Province, Madagascar, by J.B. Ramanamanjato, A. Raselimanana and C.J. Raxworthy; UMMZ 203632, male, collected 7 December 1991, Nouvelle Cascade (by Botanical Gardens), Montagne d'Ambre National Park, $12^{\circ} 31^{\prime} \mathrm{S}, 49^{\circ} 11^{\prime} \mathrm{E}, 1000 \mathrm{~m}$ altitude, Antsiranana Fivondronana, Antsiranana (Diégo Suarez) Province, Madagascar, by J.B. Ramanamanjato, A. Raselimanana and C.J. Raxworthy; UMMZ 203633-4, males, collected 26 and 27 December 1991, Antomboka River Fitsahana, Montagne d'Ambre National Park, $12^{\circ} 29^{\prime} \mathrm{S}, 49^{\circ} 10^{\prime} \mathrm{E}, 650 \mathrm{~m}$ altitude, Antsiranana Fivondronana, Antsiranana (Diégo Suarez) Province, Madagascar, by J.B. Ramanamanjato, A. Raselimanana and C.J. Raxworthy.

Diagnosis - A Brookesia with a complete series of 12 , dorsolateral pointed tubercles on the body; no well-defined pelvic shield in the sacral region; no dorsal ridge (keel); no prominent pointed tubercles on the tail, chin or around the cloaca; supraocular cone rounded and does not project further forward than nostril; the horizontal distance between the snout tip and anterior margin of eye is less than the eye diameter; dorsal region of body unmarked, or with a thin dark brown vertebral line; SVL up to $55 \mathrm{~mm}$.

Only two other species, Brookesia karchei and B. valerieae share the following combination of characters with $B$. ambreensis: series of dorsolateral pointed tubercles along body, absence of prominent pointed tubercles on tail, chin and around cloaca; absence of a dorsal ridge (keel) on body; absence of a pelvic shield. Brookesia karchei has an elongated snout; the horizontal distance, between the snout tip and anterior margin of eye, is greater than the eye diameter; the supraocular cone is pointed; and is not known to exceed $30 \mathrm{~mm}$ SVL. Brookesia valerieae has nine or ten dorsolateral pointed tubercles; the supraocular cone is pointed; and the dorsal body region may have elongated, dark brown, forward pointing chevrons or a pale vertebral line.

Description of holotype-Adult male in excellent state of preservation. Hemipenes everted. The testes are grey with brown spots, enlarged; left testes $2.5 \mathrm{~mm}$ long and $1.5 \mathrm{~mm}$ wide.

Measurements in Table III. Head with lateral, orbital and posterior crests that form a dorsal helmet; divided into three regions by a pair of longitudinal parasagittal crests that start above the eyes and begin to converge before terminating at the posterior crest; between the parasagittal crests there is a pair of short parallel longitudinal crests, with a short median crest anterior and posterior to the parallel pair; posterior crest of helmet notched between parasagittal crests; three similarsized pointed tubercles on each side of posterior helmet crest, one at termination point of lateral crest, one at termination point of parasagittal crest, and one between parasagittal and lateral crests; two pointed tubercles on lateral surface of head, one just above posterior angle of mouth, and one below lateral crest in temporal region; orbital crest denticulated; supraocular cone rounded, does not project forward of the nostril; supranasal cone does not project beyond snout tip; horizontal distance between snout tip and anterior border of eye 0.9 times eye diameter; head longer than wide; chin and throat with longitudinal rows of slightly enlarged tubercles.

Dorsal surface of body flat (without a dorsal ridge or keel); 12 dorsolateral pointed tubercles form a complete longitudinal line on the body; four slightly rounded tubercles dorsally at each pointed tubercle base; most posterior (12th) pointed dorsolateral tubercle attached to a lateral pointed projection of the body above insertion point of hindlimb and projects slightly backwards; 1 st -11 th pointed dorsolateral tubercles almost equally spaced and equal in size, pointing out perpendicularly from body; slightly enlarged, rounded tubercles form undulating longitudinal crests on either side of the vertebral line between 1st and 12th dorsolateral pointed tubercles; dorsal surface of tail with slightly enlarged rounded tubercles forming two longitudinal undulating crests that continue from tailbase to halfway down the tail; no well-defined dorsal 
pelvic shield in sacral area; lateral surface of body with short longitudinal rows of slightly enlarged rounded tubercles; venter with longitudinal rows of slightly enlarged, rounded tubercles; scattered, soft-pointed tubercles on limbs; no pointed tubercles around cloaca; no pointed tubercles on tail; continuous row of slightly enlarged, rounded tubercles form longitudinal lines on ventral surfaces of tail.

The hemipenis (Fig. 2) is clavate and asymmetrical, bearing an apex with two similar-sized denticulated lobes, one pointing vertically upwards from the truncus and the other pointing laterally from the truncus. Below the lateral pointing lobe there is a papillary field. On the side opposite to the lateral denticulated lobe, attached to the entire length of the truncus and apex, there is a thin, flattened, blade-like structure with a slightly crenulate border.

In life, coloration of head, body, limbs and tail brown. Dark brown bars radiate from eye to lateral surfaces of head; a thin, dark brown vertebral line starts at neck and terminates at tailbase; chin and throat dark brown; ventral surfaces of body and tail pale brown, with dark brown blotching forming transverse bars on tail.

After three months in formalin and three months in alcohol, the only change is a darkening of pale brown pigments of the head, body and tail, which has reduced the contrast of the pattern seen in life.

Variation-Measurements of the eight paratypes are summarized in Table III. The following differences were found between the holotype and paratypes. UMMZ 200076 has few pointed tubercles on throat; UMMZ 200077 has a slightly paler brown throat and dark brown blotching. The males of this species are smaller than the females, although the sample sizes are small: male SVL $44-52 \mathrm{~mm}(n=7)$, female SVL $52-55 \mathrm{~mm}(n=2)$. No obvious sexually dimorphic features were found for other external morphological features.

Etymology - The specific name refers to the type locality Montagne d'Ambre.

Habitat and distribution.-All specimens collected in primary rainforest. UMMZ 200074 collected at night, roosting on vegetation; UMMZ 200075 collected at 16:00 h, from the forest floor; UMMZ 200076 collected during the day, from the forest floor; UMMZ 200077 collected at night, roosting on shrubs; UMMZ 203631 collected at night, roosting at $1 \mathrm{~m}$ height; UMMZ 203632 collected at 11:30 h, on a tree trunk at $1 \mathrm{~m}$ height; UMMZ 203633 collected at 20:0022:00 h, roosting on leaves; UMMZ 203634 collected at night roosting on vegetation; UMMZ 203635 collected in a pitfall trap. All known specimens were collected between 650 and $1150 \mathrm{~m}$ altitude at Montagne d'Ambre, within the National Park and Parcel 2 of the Special Reserve. This species is probably endemic to Montagne d'Ambre.

Remarks-Muscle and liver tissue were removed prior to preservation of two paratypes (UMMZ 200074 and 200077).

\section{Brookesia antakarana sp. nov.}

Fig. 2 and Plate II

Holotype-UMMZ 200071, mature male, collected 6 December 1991, Antomboka River, Montagne d'Ambre National Park, $12^{\circ} 32^{\prime} \mathrm{S}, 49^{\circ} 10^{\prime} \mathrm{E}, 1050 \mathrm{~m}$ altitude, Antsiranana Fivondronana, Antsiranana (Diégo Suarez) Province, Madagascar, by J.B. Ramanamanjato, A. Raselimanana and C.J. Raxworthy.

Paratypes-UMMZ 200068-9, male and female collected 15 January 1991, Montagne d'Ambre National Park, $12^{\circ} 31^{\prime} \mathrm{S}, 49^{\circ} 09^{\prime} \mathrm{E}, 900 \mathrm{~m}$ altitude, Antsiranana Fivondronana, Antsiranana (Diégo Suarez) Province, Madagascar, by J.B. Ramanamanjato and A. Raselimanana; 
UMMZ 200070, male, collected 3 November 1991, Antomboka River, Montagne d'Ambre National Park, $12^{\circ} 32^{\prime} \mathrm{S}, 49^{\circ} 10^{\prime} \mathrm{E}, 1150 \mathrm{~m}$ altitude, Antsiranana Fivondronana, Antsiranana (Diégo Suarez) Province, Madagascar, by J.B. Ramanamanjato, A. Raselimanana and C.J. Raxworthy; UMMZ 200072, male, collected 26 December 1991, Antomboka River Fitsahana, Montagne d'Ambre National Park, $12^{\circ} 29^{\prime} \mathrm{S}, 49^{\circ} 10^{\prime} \mathrm{E}, 650 \mathrm{~m}$ altitude, Antsiranana Fivondronana, Antsiranana (Diégo Suarez) Province, Madagascar, by J.B. Ramanamanjato, A. Raselimanana and C.J. Raxworthy; UMMZ 203636-9, male, female, male, female, collected 17, 18, 18, 21 November 1991, Antomboka River, Montagne d'Ambre National Park, $12^{\circ} 32^{\prime} \mathrm{S}, 4^{\circ} 10^{\prime} \mathrm{E}$, 1050-1200 m altitude, Antsiranana Fivondronana, Antsiranana (Diégo Suarez) Province, Madagascar, by J.B. Ramanamanjato, A. Raselimanana and C.J. Raxworthy; UMMZ 203640-1, male and female, collected 25, 26 December 1991, Antomboka River Fitsahana, Montagne d'Ambre National Park, $12^{\circ} 29^{\prime} \mathrm{S}, 49^{\circ} 10^{\prime} \mathrm{E}, 650 \mathrm{~m}$ altitude, Antsiranana Fivondronana, Antsiranana (Diégo Suarez) Province, Madagascar, by J.B. Ramanamanjato, A. Raselimanana and C.J. Raxworthy.

Diagnosis-A Brookesia with a complete series of 12-13 dorsolateral pointed tubercles on the body; the 11 anterior pointed tubercles (1st-11th) almost equal in size and spacing; the most posterior (12th or 13th) pointed tubercles directed backward slightly on a pointed lateral projection of the body; a diamond-shaped pelvic shield in sacral region; no dorsal ridge (keel); pointed tubercles dorsally at the base of the neck; no enlarged pointed tubercles around the cloaca; body dorsally with three, dark brown, blunt chevrons; SVL up to $58 \mathrm{~mm}$.

Only two other species, Brookesia stumpffi and B. griveaudi, share the following combination of characters with $B$. antakarana: series of dorsolateral pointed tubercles along body, absence of a

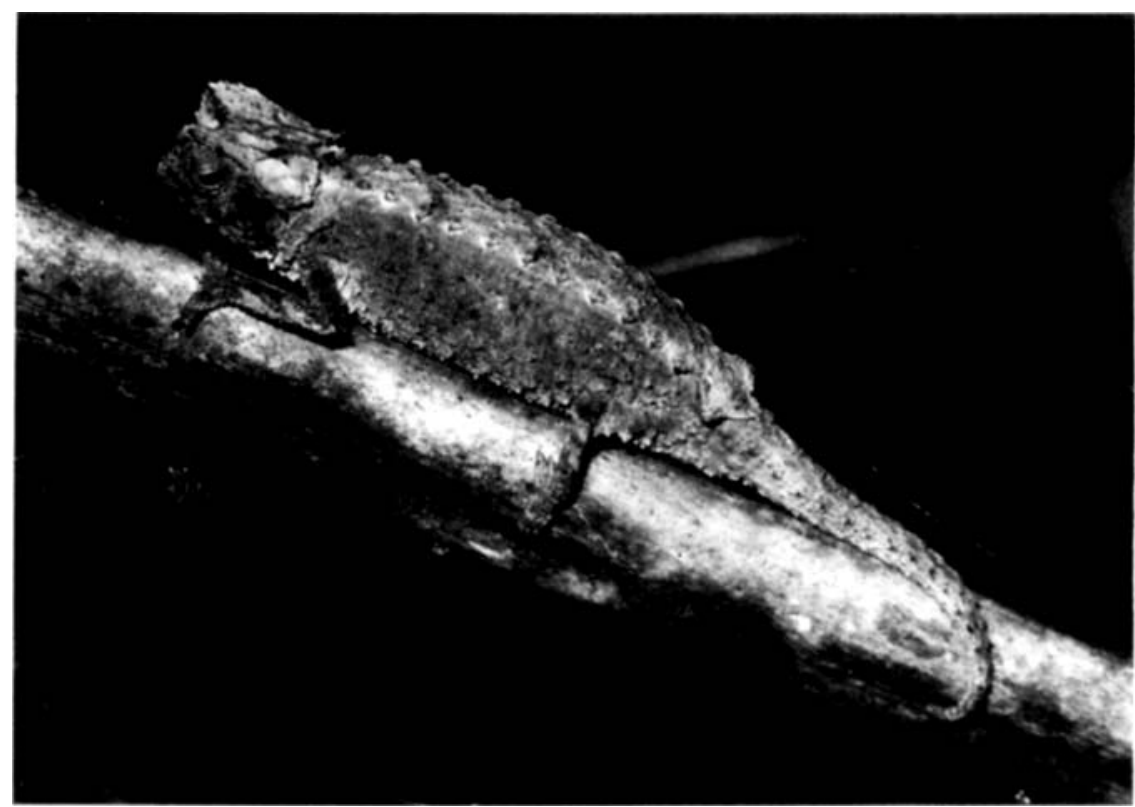

PLATE II. Brookesia antakarana sp. nov., UMMZ 203637 (paratype). 
dorsal ridge (keel) on body, absence of pointed tubercles around cloaca, and a well-defined pelvic shield. Brookesia stumpffi and $B$. griveaudi have 9-10 obvious pairs of dorsolateral pointed tubercles on the body, lack pointed tubercles dorsally at the base of the neck, and lack chevron markings between the dorsolateral pointed tubercles on the body.

Description of holotype-Adult male in excellent state of preservation. Hemipenes everted. Testes pale grey with fine brown spots, enlarged; left testis $2 \mathrm{~mm}$ long and $1 \mathrm{~mm}$ wide.

Measurements in Table III. Head with lateral, orbital and posterior crests that form a dorsal helmet; helmet divided into three regions by a pair of longitudinal parasagittal crests that start above the eyes and begin to converge before terminating at the posterior helmet crest; between parasagittal crests a short median longitudinal crest; posterior helmet crest notched between parasagittal crests; three similar-sized, pointed tubercles on each side of posterior helmet crest, one at termination point of lateral crest, one at termination point of parasagittal crest, and one between parasagittal and lateral crest; two-pointed tubercles on lateral surface of head in temporal region, just above posterior angle of mouth and below lateral crest; orbital crest strongly denticulated; supraocular cone rounded and does not project forward of the nostril; supranasal cone does not project beyond snout top; horizontal distance between snout tip and anterior border of eye equal to eye diameter; head longer than wide; chin and throat with longitudinal lines of small, slightly enlarged tubercles in four rows.

Dorsal surface of body flat (without a dorsal ridge or keel); 12 dorsolateral pointed tubercles form a complete longitudinal line on the body; three enlarged, rounded, tubercles dorsally at base of each dorsolateral pointed tubercle; posteriormost (12th) dorsolateral pointed tubercle attached to a pointed lateral projection of the body above insertion of hindlimbs and directed slightly backwards; 1 st-11th anterior dorsolateral pointed tubercles almost equally spaced and equal in size, perpendicular to body; pointed tubercles form a forward-directed chevron dorsally on the neck anterior to dorsolateral pointed tubercles; slightly raised, round, tubercles form posteriorly directed chevrons on the vertebral line between 1st and 10th dorsolateral pointed tubercles; a well-defined, dorsal pelvic shield forms an almost square-shaped diamond in the sacral area; body laterally with well-separated, soft-pointed tubercles which do not form rows; venter with faint longitudinal rows of slightly enlarged tubercles; scattered soft-pointed tubercles on limbs; no pointed tubercles around cloaca; 17 small-pointed tubercles on tail forming a longitudinal dorsolateral row from tailbase nearly to tail tip; continuous rows of small-pointed tubercles form longitudinal lines on ventral surfaces of tail.

The hemipenis (Fig. 2) is clavate and asymmetrical, bearing an apex with two similar-sized denticulated lobes. Below one of the lobes there is a papillary field. There are no lateral projections on the truncus and apex.

In life, coloration of head, body, limbs and tail are brown. Dorsal and lateral surfaces of head dark brown; dark brown bars radiate from eye on to lateral surface of head; dark brown spots on the supra- and infralabials; tubercles on dorsal surface of neck dark brown; three dark brown forward pointing chevrons on vertebral line of body at level of 4th, 7th and 10th pair of dorsolateral pointed tubercles, each chevron blunt, with an internal apical angle of $90^{\circ}$; pelvic shield dark brown on edges and with a broken, dark brown, vertebral line; tail dorsally with dark brown blotches; chin and throat brown, with two longitudinal rows of dark brown blotches; venter dark brown and unspotted; tail pale brown below, with dark brown blotching forming transverse bars on posterior ventral half of tail.

After three months in formalin and three months in alcohol, the pale brown pigments of the head, body and tail have become grey, otherwise coloration is unchanged. 
Variation-Measurements of the ten paratypes are summarized in Table III. The following variation was found between the holotype and paratypes. UMMZ 200068 has one dorsolateral pointed tubercle on the tail. UMMZ 200069 has an additional pair of short parallel crests on the head, anterior to the median head crest; no spotting on throat; and seven dorsolateral pointed tubercles on the tail. UMMZ 200070 has the 2 nd, left dorsolateral pointed tubercle of the body positioned immediately behind the 1st, resulting in unequal spacing of the left row of pointed tubercles; 11 dorsolateral pointed tubercles on the tail; and chevrons between the 5th, 8th and 10 th dorsolateral pointed tubercles of the body. UMMZ 200072 with anterior ridges of the pelvic shield that do not unite by $3 \mathrm{~mm}$ on the vertebral line; 16 dorsolateral pointed tubercles on the tail; and a chevron marking only between the 4th dorsolateral pointed tubercles of the body. UMMZ 203641 has 13 dorsolateral pointed tubercles on the body, the anterior 12 being equally spaced and equal in size.

Three of the four female paratypes are larger (SVL $55-58 \mathrm{~mm}$ ) than all seven male types (SVL $45-52 \mathrm{~mm}$ ) suggesting sexual differences in body size. No other obvious external sexually dimorphic features were found.

Etymology-The specific name refers to the Antakarana people and region of northern Madagascar, where this species appears to be restricted.

Habitat and distribution-UMMZ 200068-9 collected during the day on the forest floor; UMMZ 200070 collected at $20: 00 \mathrm{~h}$, roosting on a branch at $0.8 \mathrm{~m}$ height; UMMZ 200071 collected at $12: 00 \mathrm{~h}$, from a fern leaf at $1.5 \mathrm{~m}$ height; UMMZ 200072 collected at $20: 00 \mathrm{~h}$, roosting on a leaf; UMMZ 203636 collected at $20: 00 \mathrm{~h}$, roosting at $1.5 \mathrm{~m}$ height; UMMZ 203637-8 collected at 00:00-01:00 h, roosting; UMMZ 203639 collected at night, roosting at $0.25 \mathrm{~m}$ height; UMMZ 203640 collected at night, roosting; UMMZ 203641 collected at 20:00-22:00 h, roosting on leaves. All known specimens were collected in rainforest between 650-1200 m altitude at Montagne d'Ambre, within the National Park and from Parcel 2 of the Special Reserve. This species is probably endemic to Montagne d'Ambre.

\section{Brookesia bekolosy sp. nov.}

Fig. 2 and Plate III

Holotype-UMMZ 200078, mature male, collected 8 March 1992, Bekolosy, Manongarivo Special Reserve, $14^{\circ} 03^{\prime} \mathrm{S}, 48^{\circ} 18^{\prime} \mathrm{E}, 1200 \mathrm{~m}$ altitude, Ambanja Fivondronana, Antsiranana (Diégo Suarez) Province, Madagascar, by C.J. Raxworthy.

Paratypes-None.

Diagnosis-A Brookesia with a straight dorsal ridge (keel) on the body; an incomplete series of six, dorsolateral pointed tubercles on the anterior region of the body; no pelvic shield; and no pointed tubercles on the chin.

Only two other spec,es, Brookesia superciliaris and $B$. therezieni have a straight dorsal ridge on the body. Brookesia superciliaris and $B$. therezieni have a complete series of 10-11 dorsolateral pointed tubercles on the body and pointed tubercles on the chin.

Description of holotype-Adult male in excellent state of preservation. The liver is missing (removed prior to preservation, and frozen in liquid nitrogen). Hemipenes everted. Testes are white and enlarged; left testis $2 \mathrm{~mm}$ long and $1.5 \mathrm{~mm}$ wide.

Snout-vent length $34 \mathrm{~mm}$; tail $28 \mathrm{~mm}$; maximum head depth $5 \mathrm{~mm}$, width $5 \mathrm{~mm}$; axilla-groin distance $16 \mathrm{~mm}$; maximum body depth $9 \mathrm{~mm}$, width $4 \mathrm{~mm}$. Head with lateral and orbital crests, but no posterior crest; head dorsally with enlarged, rounded tubercles forming a pair of 


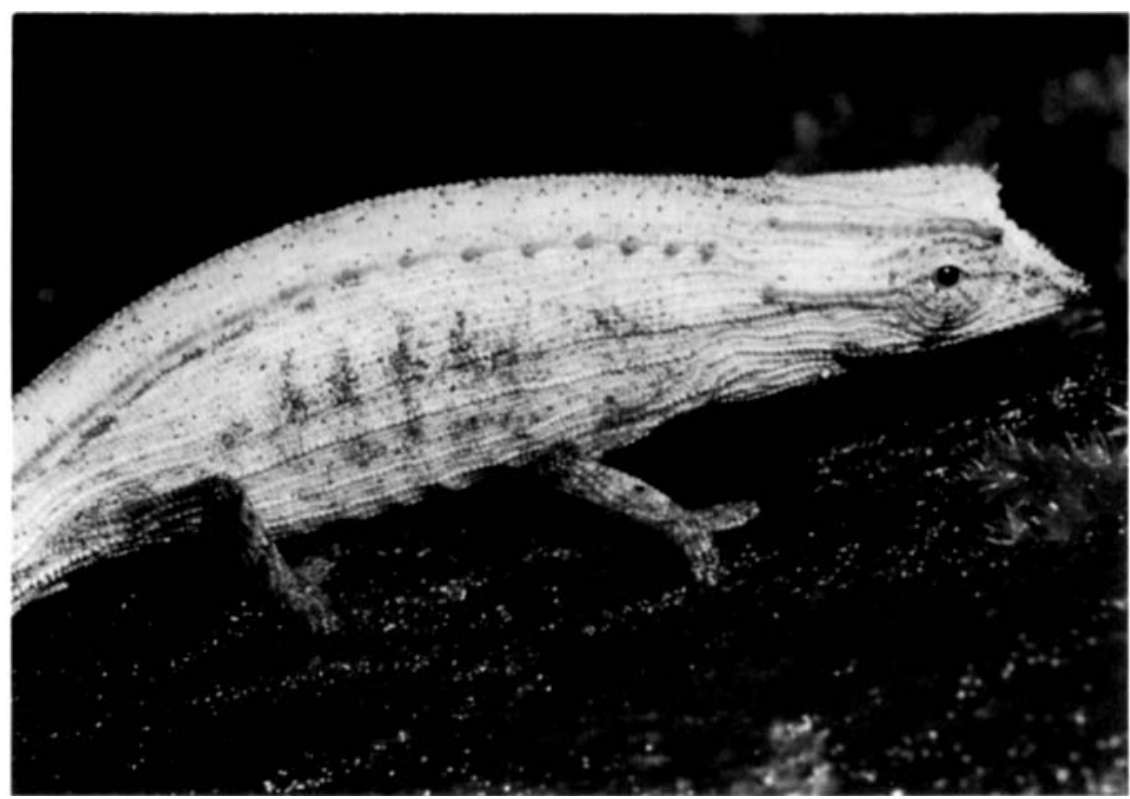

Plate III. Brookesia bekolosy sp. nov. UMMZ 200078 (holotype).

longitudinal parasagittal crests which start above the eyes and begin to converge before terminating at the posterior region of head; between parasagittal crests, a median line of rounded tubercles form a crest from snout to posterior region of head; lateral and orbital crest almost straight-edged when viewed laterally; orbital crest slightly denticulated; supraocular cone pointed and does not project beyond nostril; no supranasal cone; elongated snout with horizontal distance between snout tip and anterior border of eye 1.5 times eye diameter; head longer than wide; two longitudinal lines of rounded tubercles start behind the eye and terminate at neck at an enlarged pointed tubercle on the neck; chin smooth.

Body with dorsal ridge (keel) marked by two vertebral rows of slightly enlarged rounded tubercles; six dorsolateral pointed tubercles form an incomplete longitudinal line on body, starting at neck, the tubercles decreasing in size posteriorly until at midbody replaced by a continuous row of slightly enlarged rounded tubercles which continue to tail tip; dorsolateral pointed tubercles without enlarged tubercles at their base dorsally; an enlarged rounded tubercle above insertion point of hindlimbs, just below dorsolateral longitudinal row of tubercles; no pelvic shield; body laterally with regular longitudinal rows of slightly enlarged, rounded tubercles; venter with longitudinal rows of slightly enlarged rounded tubercles in sacral area; no pointed tubercles on limbs; no pointed tubercles around cloaca; no pointed tubercles on tail; rows of slightly enlarged rounded tubercles form longitudinal lines on ventral surface of tail.

The hemipenis (Fig. 2) is clavate and symmetrical, bearing an apex that is cup-shaped with a shallow sunken centre. The thin and delicate symmetrical rim on the lateral and sulcal surface of the apex suggest to us that the central depression is not an artefact of incomplete hemipenis eversion. Within the central depression there is a small pair of smooth lobes. The apex rim is 
much lower on the sulcal side, with a small pair of round lobes on either side of the median line. The truncus and apex lack other lateral structures.

In life, coloration of head, body, limbs and tail brown with a darker brown spot at base of head anterior to dorsal ridge; tail tip orange. Ventrally head, body and tail pale brown with a faint dark brown median line from throat nearly to tail tip.

After three months in formalin and three months in alcohol, the only change is a darkening of the pale brown pigments of the head, body and tail.

Etymology - The specific name refers to the type locality, the Bekolosy Plateau at Manongarivo.

Habitat and distribution--The holotype was collected at $22: 00 \mathrm{~h}$, roosting on a thin branch at $1 \mathrm{~m}$ height, in primary rainforest at $1200 \mathrm{~m}$ altitude on a ridge. No other locality is presently known for this species. The rainforest at Berkolosy is high altitude, with the forest canopy typically between $5-10 \mathrm{~m}$ in height, and tree branches heavily draped with lichens. A more intensive survey was made by us at lower elevation forests in the Manongarivo Reserve (between $50-800 \mathrm{~m}$ ). The absence of this species at these lower altitudes makes us think it is restricted to higher elevation forest, probably in excess of $1000 \mathrm{~m}$. This species is probably restricted to rainforest in the Northwest biogeographic region (see below).

\section{Brookesia brygooi sp. nov.}

Holotype-MHNP 8219, female, collected at Analavelona, Southwest Madagascar by H. Humbert.

Paratype-BM 1968.691, female, collected from Sakaraha, Southwest Madagascar by K.M. Guichard.

Other specimens-507/C, 553/C (males), collected from Kasijy, $150 \mathrm{~km}$ south of Mitsingy, West Madagascar; $533 / \mathrm{C}$ (female), collected from $50 \mathrm{~km}$ north of Toliara, Southwest Madagascar. These specimens, reported by Brygoo (1978) and Brygoo \& Domergue (1971), are probably held at MHNP.

Diagnosis-A Brookesia without a dorsal ridge (keel) on the body; a complete series of dorsolateral pointed tubercles on the body; a pelvic shield; a ventrolateral pointed tubercle on the tailbase posterior to the cloaca; and a head width in temporal region $1 \cdot 0-1 \cdot 2$ times wider than the width between eyes.

Only Brookesia decaryi and B. bonsi share the following combination of features: body without a dorsal ridge, a complete series of dorsolateral pointed tubercles on the body, a pelvic shield and a ventrolateral pointed tubercle on the tailbase posterior to the cloaca. However, the head width in the temporal region of both Brookesia decaryi and $B$. bonsi is 1.3-1.5 times wider than the width between eyes.

Description of holotype-Based on Brygoo (1978). Female (probably gravid). Snout-vent length $46 \mathrm{~mm}$; tail $28 \mathrm{~mm}$. Head with lateral, orbital and posterior crests that form a dorsal helmet; helmet divided into three regions by a pair of longitudinal parasagittal crests that start above the eyes and begin to converge before terminating at the posterior helmet crest; three pointed tubercles on each side of posterior helmet crest, one at termination point of lateral crest, one at termination point of parasagittal crest, and one between parasagittal and lateral crest; two pointed tubercles on lateral surface of head, one just above posterior angle of mouth and one below lateral crest in temporal region; orbital crest denticulated; supraocular cone rounded and projects forward to level of nostril; supranasal cone does not reach as far forward as snout tip. 
Dorsal surface of body flat (without a dorsal ridge or keel); 10 dorsolateral pointed tubercles form a complete longitudinal line on body; posteriormost (10th), pointed dorsolateral tubercle projects posteriorly from a pelvic shield above insertion point of hindlimbs; 1 st-9th anterior pointed tubercles equally spaced and almost equal in size, perpendicular to body; a ventrolateral pointed tubercle just posterior to cloaca on the tailbase; no dorsolateral pointed tubercles on the tail.

Variation-Brygoo (1978) reported the following variation: maximum SVL $52 \mathrm{~mm}$ (females), $48 \mathrm{~mm}$ (males); maximum tail length $38 \mathrm{~mm}$ (females), $33 \mathrm{~mm}$ (males); the tail of BM 1968.691 has a series of four small dorsolateral pointed tubercles. The hemipenis of $507 / \mathrm{C}$ is clavate and asymmetrical, bearing an apex with a small denticulated lobe and a large papillary field (Brygoo \& Domergue, 1971).

Etymology - The specific name honours Dr E. R. Brygoo, who first described specimens of this new species, and contributed to the understanding of Brookesia systematics.

Habitat and distribution--In addition to the localities given for the holotype, paratype and other specimens, Brygoo (1978) reported specimens (without calalogue numbers) from Bemaraha (Réserve Naturelle Intégrale No. 11) and Antsalova, also in the Southwest. Brookesia brygooi is found in the arid Southwest and West of Madagascar, occurring between $17-23^{\circ} \mathrm{S}$, and is probably restricted to native deciduous forests in these regions. Brookesia brygooi is one of the few arid-adapted species of the genus. The other species found in arid habitats of the Western Domain are $B$. bonsi, $B$. decaryi, B. perarmata and B. stumpffi.

Remarks-Illustrations of the holotype, 507/C and 533/C are given by Brygoo (1978). Brookesia brygooi was previously confused with $B$. ebenaui (see above).

\section{Brookesia lineata sp. nov.}

Fig. 2 and Plate IV

Holotype-UMMZ 200073, mature male, collected 8 March 1992, Bekolosy, Manongarivo Special Reserve, $14^{\circ} 03^{\prime} \mathrm{S}, 48^{\circ} 18^{\prime} \mathrm{E}, 1200 \mathrm{~m}$ altitude, Ambanja Fivondronana, Antsiranana (Diégo Suarez) Province, Madagascar, by A. Raselimanana.

Paratypes-None.

Diagnosis-A Brookesia with a complete series of 11 dorsolateral pointed tubercles on the body; a lateral projection of the body in the sacral area forms a straight-edged ledge with the 11th dorsolateral pointed tubercle on its posterior border; no pelvic shield in the sacral region; no dorsal ridge (keel); no pointed tubercles around the cloaca or on the tail; supraocular cone projects forward to same level as supranasal cone; four soft-pointed tubercles on chin; $45 \mathrm{~mm} \mathrm{SVL}$.

Only two other species, Brookesia betschi and B. thieli, share the following combination of characters: series of complete dorsolateral pointed tubercles along body; elongated pointed tubercles on chin; absence of pointed tubercles around cloaca; absence of a dorsal ridge (keel) on body, absence of a pelvic shield. Brookesia thieli and $B$. betschi both have a pointed lateral projection of the body above the hindlimb; the supraocular cone may project forward further than the supranasal cone; and they are not known to exceed $42 \mathrm{~mm}$ SVL.

Description of holotype-Adult male in excellent state of preservation. The left hindlimb and liver are missing (removed prior to preservation, and frozen in liquid nitrogen). Hemipenes everted. Testes pale yellow, enlarged: left testis $2.5 \mathrm{~mm}$ long and $2 \mathrm{~mm}$ wide.

Snout-vent length $45 \mathrm{~mm}$; tail $32 \mathrm{~mm}$; maximum head depth $8 \mathrm{~mm}$, width $8 \mathrm{~mm}$; axilla-groin distance $24 \mathrm{~mm}$; maximum body depth $11 \mathrm{~mm}$, width $6 \mathrm{~mm}$. Head with lateral, orbital and 


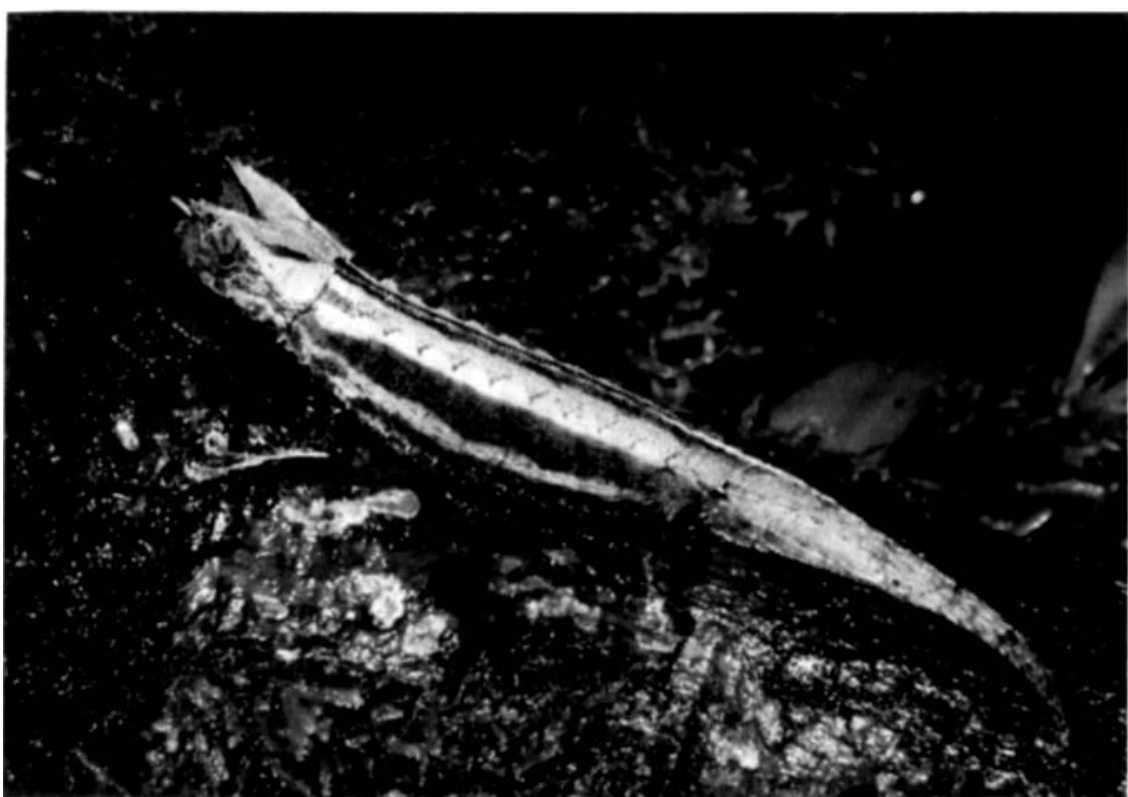

PlAte IV. Brookesia lineata sp. nov., UMMZ 200073 (holotype).

posterior crests that form a dorsal helmet; helmet divided into three regions by a pair of longitudinal parasagittal crests that start above the eyes and begin to converge before terminating at the posterior helmet crest; between the parasagittal crests there are three longitudinal crests, a broken median crest and two lateral crests; posterior crest of helmet notched between parasagittal crests; three pointed tubercles on right side of posterior helmet crest, largest at termination point of lateral crest, smallest at termination point of parasagittal crest, third between parasagittal and lateral crest; one pointed tubercle on left side of head at termination point of parasagittal crest; two pointed tubercles on lateral surface of head, one just above posterior angle of mouth and one below lateral crest in temporal region; orbital crest strongly denticulated; supraocular cone pointed and projects forward of nostril to same level as supranasal cone; horizontal distance between snout tip and anterior border of eye equal to eye diameter; head longer than wide; supranasal cone does not project beyond snout tip; chin with four, elongated soft tubercles in two longitudinal rows, on right side both tubercles pointed, on left side one tubercle pointed and one rounded.

Dorsal surface of body flat (without a dorsal ridge or keel); 11 dorsolateral pointed tubercles form a complete longitudinal line on body; three, enlarged, rounded tubercles dorsally at each dorsolateral pointed tubercle base; most posterior (11th) pointed dorsolateral tubercle projects posteriorly from a straight-edged lateral projection of the body that forms a ledge above insertion of hindlimb; 1st-10th anterior pointed tubercles equally spaced and almost equal in size, perpendicular to body; space between 10th and 11th pointed tubercles 1.5 times greater than interval between anterior tubercles; the vertebral line on the body has incomplete posteriorly directed chevrons and a double row of slightly enlarged, rounded tubercles; no dorsal pelvic shield in sacral area; slightly enlarged, rounded tubercles form a longitudinal row ventral to the 1st-11th, dorsolateral, pointed tubercles; body laterally with short, longitudinal rows of slightly 
enlarged, rounded tubercles, and scattered pointed tubercles in ventrolateral region; venter with scattered pointed tubercles; scattered, soft-pointed tubercles on limbs; no pointed tubercles around cloaca; no pointed tubercles on tail; continuous longitudinal rows of slightly enlarged, rounded tubercles on ventrolateral and ventral surfaces of tail.

The hemipenis (Fig. 2) is clavate and symmetrical, bearing a bi-lobed apex, each lobe with a single denticulated crest, with the strongest denticulations on the distal surface of the apex. The truncus and apex are without lateral projections.

In life, the coloration of head, body and tail brown. Dark brown spotting between supraocular cones of head; parasagittal crests lined dark brown; dark brown bars radiate from eye on lateral surface of head; vertebral line of body pale brown, becoming pale yellow in sacral region, and fading at tailbase; vertebral line bordered by thin, dark brown lines starting from behind head and fading in sacral region; a short, dark brown, dorsolateral, longitudinal line starts at posterior crest of helmet and terminates at 1st dorsolateral pointed tubercle; body laterally with two, dark brown, longitudinal lines, superior line starts at neck and terminates at tailbase, inferior line thin and broken, starts at neck and terminates at insertion of hindlimb; tail marked dorsally with four, transverse, dark brown bars; limbs dark brown; chin white with a pair of dark brown crescentshaped spots facing each other on the median line, and a dark brown blotch at chin tip; throat, venter and ventral surface of tail pale brown and blotched with darker brown.

After three months in formalin and three months in alcohol, the only change is a darkening of the pale brown pigments or the head, body and tail, which has reduced the contrast of the pattern seen in life.

Etymology - The specific name refers to the unusual dark lines on the body of this species.

Habitat and distribution - The holotype was collected at night, roosting on a leaf at $1 \mathrm{~m}$ height, in primary rainforest at $1200 \mathrm{~m}$ altitude on a ridge. No other locality is presently known for this species. For additional information see comments on habitat for Brookesia bekolosy.

Remarks-Brookesia lineata is unusual in that the flanks are marked by bold, dark brown, longitudinal lines. Brygoo (1978) does not describe such a coloration pattern for any other Brookesia species, although dark flank lines occur in male Brookesia thieli (UMMZ 196217-8).

\section{Brookesia lolontany sp. nov.}

Plate V

Holotype-UMMZ 203629, mature female, collected 29 March 1993, Matsabory Lake, Tsaratanana, $14^{\circ} 09^{\prime} \mathrm{S}, 48^{\circ} 58^{\prime} \mathrm{E}, 2050 \mathrm{~m}$ altitude, Bealanana Fivondronana, Mahajanga Province, Madagascar, by Angeluc Razafimanantsoa.

Paratype-UMMZ 203630, female, collected 1 April 1993, Befosa River, Tsaratanana, $14^{\circ} 11^{\prime} \mathrm{S}, 48^{\circ} 57^{\prime} \mathrm{E}, 1600 \mathrm{~m}$ altitude, Bealanana Fivondronana, Mahajanga Province, Madagascar, by Angeluc Razafimanantsoa.

Diagnosis-A Brookesia without dorsolateral pointed tubercles on the body; a dorsal ridge (keel) on the body that is strongly convex; integumentary lobe on the snout tip; and a dorsal helmet that is strongly pointed posteriorly.

Only one other species, Brookesia nasus, has a strongly convex dorsal body ridge, but this species can be readily separated from $B$. lolontany by the condition of the snout tip which has two pointed tubercles and of the helmet which is not pointed posteriorly.

Description of holotype-Adult female in excellent state of preservation. The liver and left 


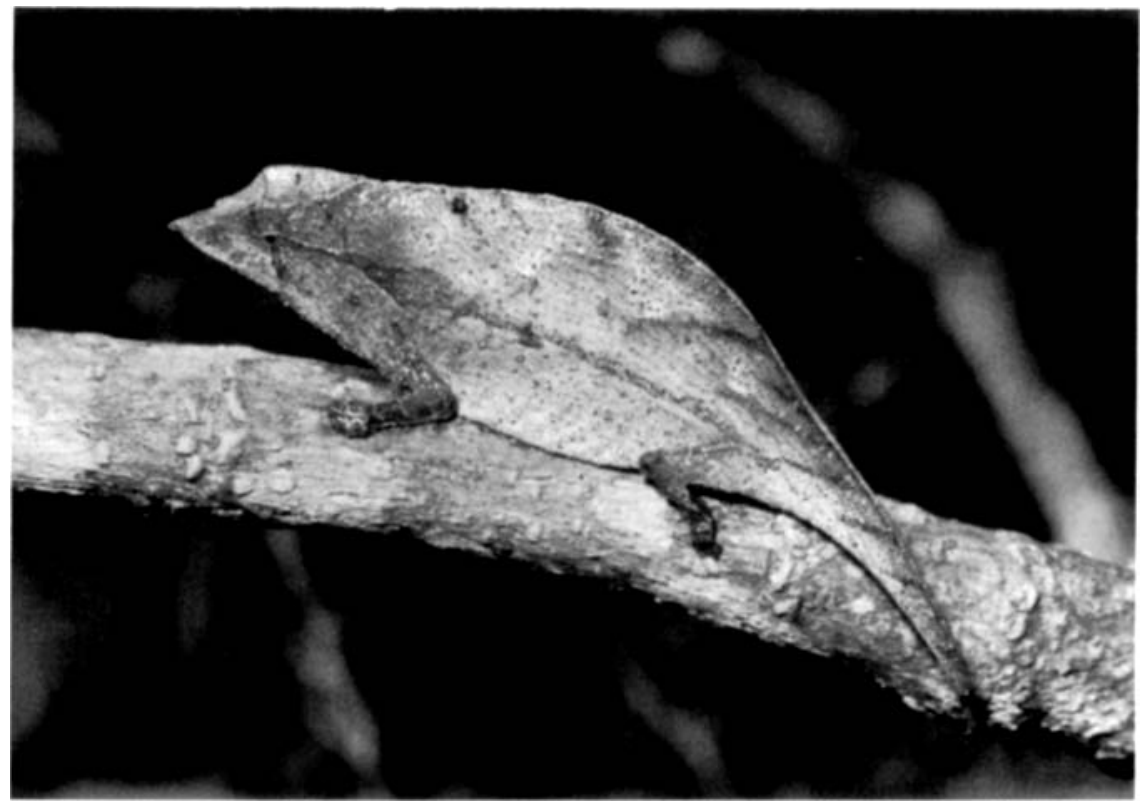

Plate V. Brookesia lolontany sp. nov., UMMZ 203629 (holotype).

hindlimb were removed before fixation and frozen in liquid nitrogen. The left oviduct contains three pale yellow round eggs, the largest $2 \mathrm{~mm}$ in diameter.

Snout-vent length $32 \mathrm{~mm}$; tail $18 \mathrm{~mm}$; maximum head depth $9 \mathrm{~mm}$, width $5 \mathrm{~mm}$; axilla-groin distance $15 \mathrm{~mm}$; maximum body depth $12 \mathrm{~mm}$, width $6 \mathrm{~mm}$. Head with orbital and parasagittal crests that converge posteriorly and unite on the median line at the posterior limit of the head to form a helmet with a sharp point; a pointed tubercle on lateral surface of head in temporal region; a crest of rounded tubercles starts behind eye and terminates at the temporal pointed tubercle; orbital crest smooth; supraocular cone low and rounded; supranasal cone hardly visible and positioned in front of nostril; snout tip with a soft integumentary lobe $0.7 \mathrm{~mm}$ long, that projects forwards, tapers to a blunt point and is flattened laterally; horizontal distance between snout tip and anterior border of eye two times eye diameter; head longer than wide; chin and throat with a few, slightly enlarged, rounded tubercles.

Body dorsally, with a convex dorsal ridge (keel); no dorsolateral pointed or rounded tubercles on the body even in sacral region; on the vertebral body ridge, slightly enlarged rounded tubercles form an alternating single and double longitudinal row with nine slight undulations; dorsal surface of tail with slightly enlarged, rounded tubercles forming a double row on the vertebral line; no dorsal pelvic shield in sacral area; ventrolaterally body with scattered, slightly enlarged, rounded tubercles; venter with short longitudinal rows of slightly enlarged, rounded tubercles; a few, scattered pointed tubercles on limbs; no pointed tubercles around cloaca; no pointed tubercles on tail; rows of slightly enlarged rounded tubercles on ventral surface of tail.

In life, coloration of head, body, limbs and tail brown. A pale brown bar starts below eye and terminates just anterior to corner of mouth; lateral and vertebral crests are pale brown; body with 
a thin, dark brown, longitudinal line that starts at temporal tubercle and terminates just above hindlimbs; chin and throat dark brown; venter and tail undersurface pale brown with a median, thin, dark brown, longitudinal line starting on throat and fading halfway along tail.

After three months in formalin and three months in alcohol, the only change is a slight reduction in the contrast of the pattern seen in life.

Variation - The paratype measurements are SVL $28 \mathrm{~mm}$; tail $15 \mathrm{~mm}$; maximum head depth $7 \mathrm{~mm}$, width $5 \mathrm{~mm}$; axilla-groin distance $14 \mathrm{~mm}$; maximum body depth $11 \mathrm{~mm}$, width $5 \mathrm{~mm}$. The following differences were found in the paratype: orbital crest slightly denticulated; snout tip with a soft integumentary lobe $0.5 \mathrm{~mm}$ long, rounded and directed forwards and upwards; horizontal distance between snout tip and anterior border of eye 1.5 times eye diameter; no undulations visible on dorsal body ridge. The anterior $2 \mathrm{~mm}$ of the dorsal body ridge is pale yellow; lateroventrally the body has a thick, pale brown, undulating, longitudinal line with dark brown borders; pale brown spots on both sides of vertebral ridge; chin and throat pale brown with dark brown spots; venter without dark median line.

Etymology - The specific name "lolontany" is the Malagasy name of the Tsaratanana mountain spirits that are believed to occupy the forests where the types were collected.

Habitat and distribution-UMMZ 203629 collected at $20: 00 \mathrm{~h}$, roosting on a leaf at $0.7 \mathrm{~m}$ height, in bamboo dominated primary rainforest; UMMZ 203630 collected at 20:00 h, roosting on a branch at $0.05 \mathrm{~m}$ height, in primary rainforest. Both specimens were collected in the Tsaratanana mountain range, which includes the highest mountain in Madagascar, Maromokotro, at $2876 \mathrm{~m}$ altitude. The holotype of Brookesia lolontany was collected at a higher altitude than any other Brookesia species. This species is probably restricted to high altitude rainforest in the Tsaratanana Mountains.

Remarks - The only other species known to occur at a similarly high elevation is Brookesia nasus, which has been collected up to $1650 \mathrm{~m}$ altitude at Andringitra. The latter species is morphologically the most similar species to Brookesia lolontany.

\section{Identification key}

1(a) Body with dorsal ridge 2

(b) Body without dorsal ridge 6

2(a) Dorsal ridge strongly convex 3

(b) Dorsal ridge almost straight 4

3(a) Snout tip with a single integumentary lobe

Head helmet strongly pointed posteriorly B. lolontany sp. nov.

(b) Snout tip with two pointed tubercles. Head $\begin{array}{ll}\text { helmet not pointed posteriorly } & \text { B. nasus }\end{array}$

4(a) Dorsolateral pointed tubercles on anterior half of body only

B. bekolosy sp. nov.

(b) Dorsolateral pointed tubercles along entire length of body

5

5(a) Pointed tubercles on lateroventral surface of tail

B. therezieni

(b) No pointed tubercles on lateroventral surface of tail

B. superciliaris 
6(a) Dorsolateral pointed tubercles form a row along

less than half of body, or are completely absent

(b) Dorsolateral pointed tubercles form a row along more than half of body

7(a) Two dorsolateral tubercles on anterior half of body, each forming a spine

B. dentata

(b) A series of more than two dorsolateral tubercles on anterior half of body, or dorsolateral tubercles not obviously enlarged

B. minima

8(a) Enlarged pointed tubercles around the cloaca on the lateroventral surface of tail

(b) No enlarged pointed tubercles around the cloaca on the lateroventral surface of tail

9(a) Head width in temporal region $1 \cdot 0-1 \cdot 2$ times width between eyes

(b) Head width in temporal region 1.3-1.5 times width between eyes

B. brygooi sp. nov.

10

10(a) Tail with pointed dorsolateral tubercles on anterior half only

B. decaryi

(b) Tail with pointed dorsoventral tubercles along entire length except tail tip

B. bonsi

11(a) Complete or almost complete diamondshaped pelvic shield on dorsal sacral area

(b) No diamond-shaped pelvic shield on dorsal sacral area

12(a) 12-13 pointed dorsolateral tubercles and dorsal chevron markings on body

B. antakarana sp. nov.

(b) 9-11 pointed dorsolateral tubercles and no dorsal chevron markings on body

13

B. griveaudi

B. stumpffi

(b) Supraocular cone rounded

B. perarmata

(b) No enlarged keeled scales on lateral surfaces of body, head longer than wide

15(a) Pointed dorsolateral tubercles on anterior third of tail same size as sacral pair

B. vadoni

(b) Pointed dorsolateral tubercles on anterior third of tail much smaller than sacral pair, or absent

16(a) Chin with a group of elongated pointed tubercles $\quad 17$

(b) Chin without elongated pointed tubercles

17(a) Sacral projection forms a straight-edged ledge laterally on body

B. lineata sp. nov.

(b) Sacral projection forms a point laterally on body 
18(a) Pointed dorsolateral tubercles on body

anterior to the sacral pair decrease in size on

posterior half of body

B. thieli

(b) Pointed dorsolateral tubercles on body anterior to the sacral pair do not decrease in size on posterior half of body

B. betschi

19(a) Horizontal distance between snout tip and anterior margin of eye greater than eye diameter

(b) Horizontal distance between snout tip and anterior margin of eye less than eye diameter

20(a) Helmet posteriorly higher than supraocular cone, pointed tubercles on tail, maximum SVL $47 \mathrm{~mm}$

B. ebenaui

(b) Helmet posteriorly level with supraocular cone, no pointed tubercles on tail, maximum SVL $27 \mathrm{~mm}$

B. karchei

21(a) Anteriormost dorsolateral pointed tubercle of tail same size as those on body anterior to sacral pair

B. lambertoni

(b) Anteriormost dorsolateral pointed tubercle of tail much smaller than those on body anterior to sacral pair, or absent

22(a) 9-10 dorsolateral pointed tubercles on body, supraocular cone pointed

B. valerieae

(b) 11 dorsolateral pointed tubercles on body, supraocular cone rounded

B. ambreensis sp. nov.

\section{Discussion}

\section{Distribution}

The distribution of the 15 Brookesia species known from northern Madagascar are shown in Figs 3 and 4. These distribution maps include data from Brygoo (1978) and Raxworthy (1991). We were unable to find the following localities given by Brygoo: Fanano, Ambatofinandrahana, $100 \mathrm{~m}$ altitude (Brookesia griveaudi); Iaraka (or Hiaraka), Maroantsetra, 600 $1000 \mathrm{~m}$ altitude (Brookesia vadoni and B. thieli). Brygoo (1978) placed the Fanano locality in the Maroantsetra area and Iaraka either in the centre of the Masoala Peninsular or just east of Maroantsetra.

We are uncertain about the reliability of the Brookesia superciliaris record from Marojejy given by Brygoo (1978). The single specimen was obtained from an unknown collector in 1967. Brookesia superciliaris was not found at Marojejy by Guillaumet et al. (1975) and ourselves. We have not examined the specimen, and therefore cannot be sure if it has been correctly identified. In the following discussion we will consider Brookesia superciliaris absent from Marojejy. 


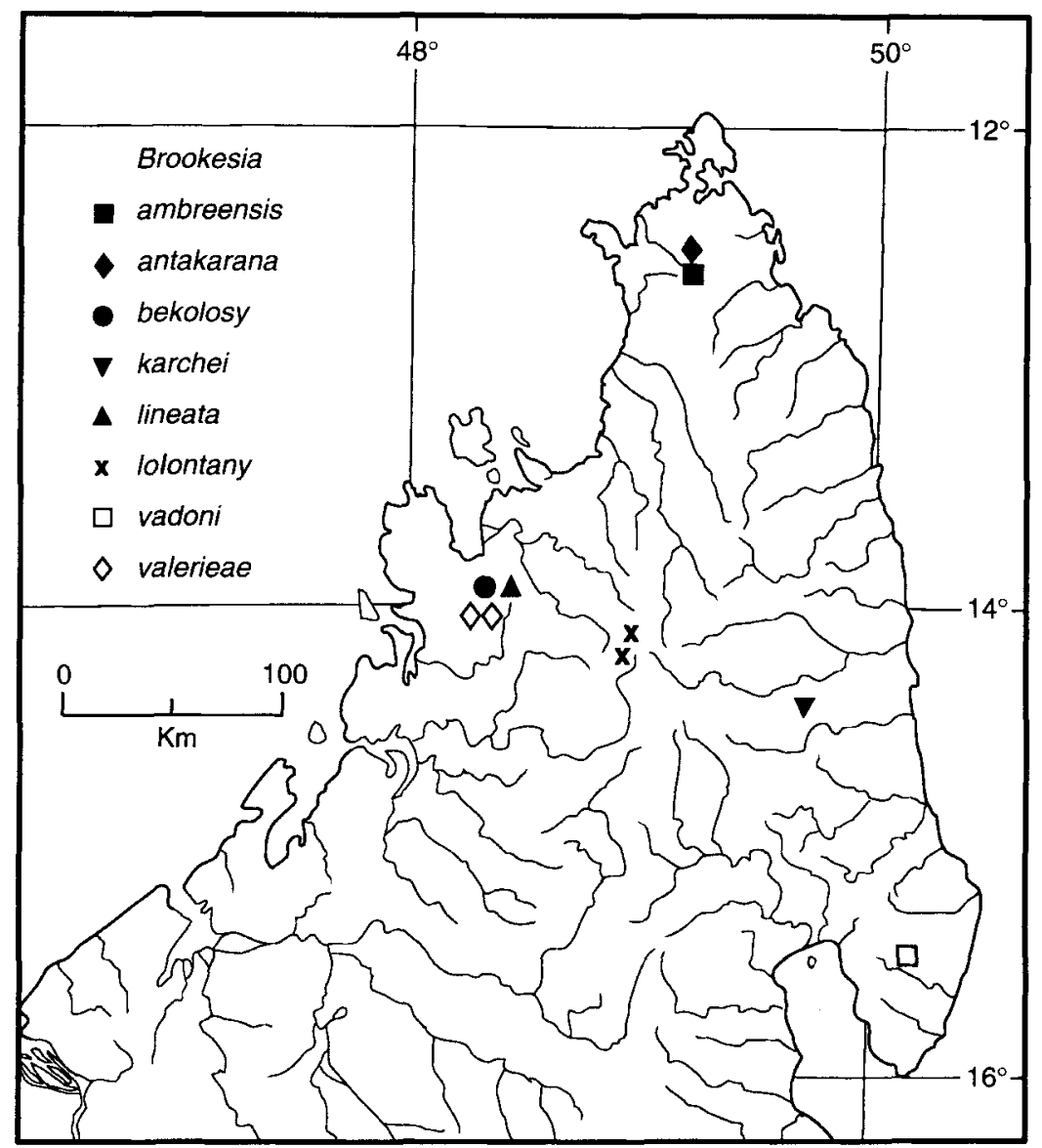

FIG. 3. Distribution of Brookesia known from a single region.

\section{Habitat}

All the Brookesia species encountered in this study were found in primary rainforest. Only one species, Brookesia stumpffi, was also found in dry forests, at Ankarana, in the limestone canyons. However, the herpetological assemblage found in these canyons suggests these forests are somewhat transitional between deciduous forest and rainforest. Brookesia stumpffi is also known from Antsiranana and Vohemar (Brygoo, 1978), and these specimens probably were collected from the drier habitats at these sites. No species of Brookesia from northern Madagascar are dry forest specialists. Brookesia decaryi is known from dry deciduous forests $300 \mathrm{~km}$ southwest of the northern rainforests. The absence of dry forest specialists in northern Madagascar may simply reflect insufficient survey work in the region.

The 15 species collected in the rainforests of northern Madagascar (north of $16^{\circ} \mathrm{S}$ ) represent $65 \%$ of the Brookesia species. This is a remarkably high percentage considering that the northern rainforests represent about one-third of the total rainforest area of the island. In terms of land mass, the northern rainforest represents only about $5 \%$ of the island's total area. Clearly, 


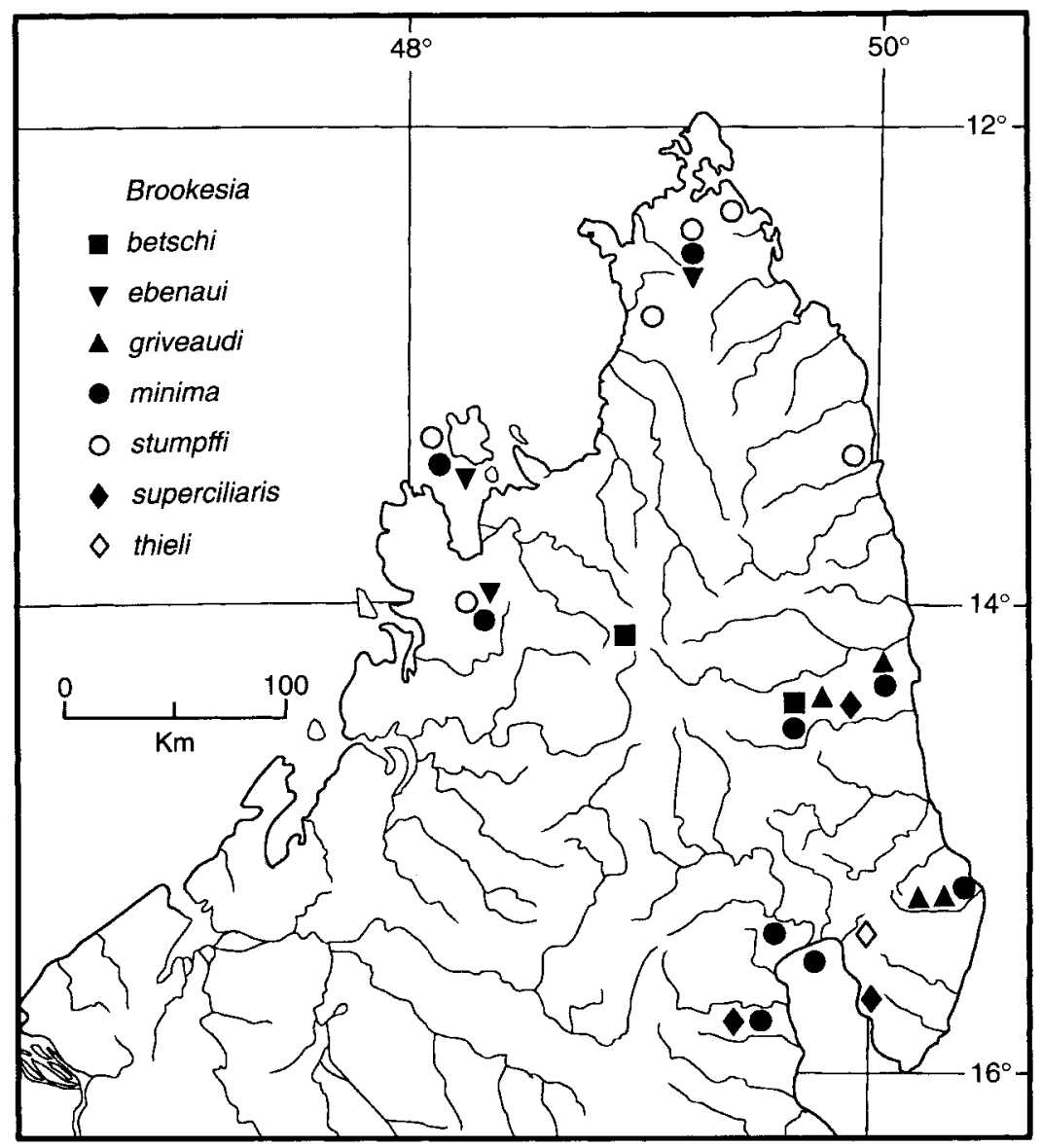

FIG. 4. Distribution of Brookesia known from multiple regions.

speciation in Brookesia has been disproportionately active in the rainforests of northern Madagascar.

\section{Altitude}

The altitudinal range of each species is shown in Fig. 5, based largely on data collected during this study, with additional data from Brygoo (1978). None of the Brookesia species is found across the full altitudinal range of rainforest that occurs in northern Madagascar. The widest altitudinal range $(0-1050 \mathrm{~m})$ is shown by Brookesia superciliaris, while 12 of the 15 species $(80 \%)$ are restricted to an altitude range of $600 \mathrm{~m}$ or less. Five species: Brookesia minima, B. ebenaui, B. griveaudi, B. stumpffi and B. superciliaris occur in low altitude rainforest close to sea-level, and, in all five cases, the upper altitude limit is between 700 and $1050 \mathrm{~m}$. Seven species: Brookesia lineata, B. bekolosy, B. antakarana, B. ambreensis, B. karchei, B. valerieae and B. vadoni are restricted to mid-altitude rainforest between 500 and $1200 \mathrm{~m}$. Just three species are known from elevations above $1200 \mathrm{~m}$ : Brookesia thieli and $B$. betschi at $900-1600 \mathrm{~m}$, and $B$. lolontany at $1600-2050 \mathrm{~m}$. 


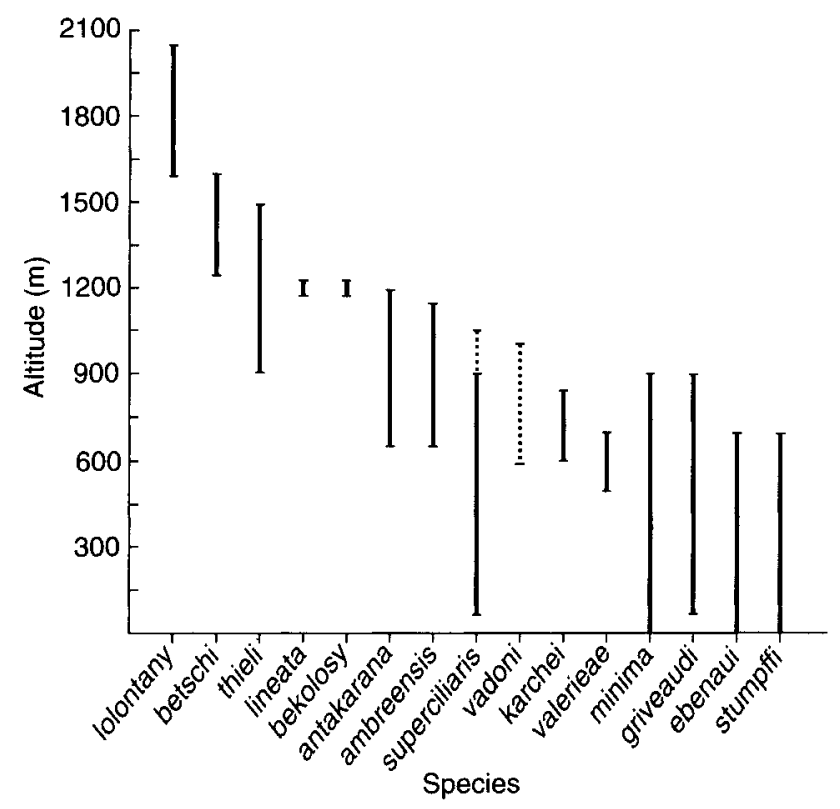

FIG. 5. Brookesia species altitude range. Solid lines represent data from this survey and Raxworthy (unpubl.), broken lines represent data from Brygoo (1978).

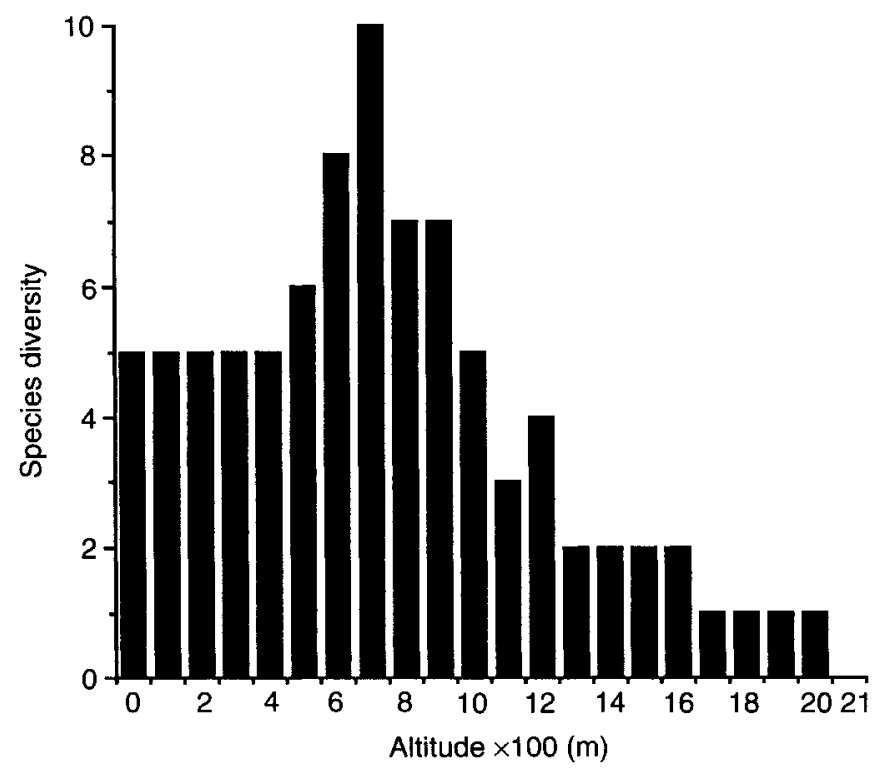

FIG 6. Brookesia species diversity as a function of altitude. 
The species diversity of Brookesia for each increment of $100 \mathrm{~m}$ altitude in the northern rainforests is shown in Fig. 6. The altitude with the greatest diversity is $700 \mathrm{~m}$ where 10 species have been recorded. Species diversity of more than five species is restricted to a narrow elevational range of $500-900 \mathrm{~m}$ altitude. The increased species diversity at $500-900 \mathrm{~m}$ altitude appears to reflect a transition zone where both low and mid-altitude specialists can coexist.

All the northern Brookesia species have a limited altitudinal range in rainforest and can be divided into three major groups: low altitude specialists that occur below $500 \mathrm{~m}$, mid-altitude specialists restricted to $500-1200 \mathrm{~m}$, and high altitude specialists that occur above $1200 \mathrm{~m}$ altitude. These three groups correlate closely with the major rainforest types described by Koechlin (1972): low altitude rainforest up to $800 \mathrm{~m}$, medium altitude rainforest between about 800 and $1300 \mathrm{~m}$, and high altitude sclerophyllous forest above $1300 \mathrm{~m}$. The altitudinal limits of these forest types, defined by the plant communities, vary somewhat depending on local relief and degree of exposure. The factors limiting the altitudinal range of Brookesia species may be directly related to a combination of climate and forest type.

\section{Biogeographic regions}

Northern Madagascar has frequently been divided into different biogeographic units because of the geological, floral and climatic complexity of the region. The phytovegetational zones for Madagascar described by Humbert (1955) have since been used as the basis for recognizing biogeographic units in Madagascar. He separated the dry and moist forest types into two regions: the Eastern and Western Regions. All the rainforests of northern Madagascar are within the Eastern Region.

The Eastern Region has been further divided into domains, with the classification of Koechlin (1972) most widely used. He defined the Centre Domain as occurring above $800 \mathrm{~m}$ altitude, having about $1.5 \mathrm{~m}$ of rainfall per annum falling almost entirely in the hot season; the High Mountains Domain as above $2000 \mathrm{~m}$, with probably large quantities of rainfall; the East Domain as below $800 \mathrm{~m}$, with $2-4 \mathrm{~m}$ of rainfall and no dry season; and the Sambirano Domain as being the extension of the East Domain west of Tsaratanana.

The distributions of all the Brookesia species in northern Madagascar (except B. minima) are limited to a small region of the rainforest, resulting in a high degree of regional endemicity. Five endemic regions can be recognized for the Brookesia species in the northern rainforest: Montagne d'Ambre, Northwest, Tsaratanana, Northeast and East. Montagne d'Ambre rainforest is completely isolated by surrounding dry forests; Tsaratanana rainforest is at high altitude (above $1200 \mathrm{~m}$ ), and flanked to the east and west by typically much lower altitude rainforest and to the north and south by dry forests; the Northwest rainforest is flanked to the east by high altitude Tsaratanana rainforest, and to the north and south by dry forests. The Northeast rainforest is bordered to the west by high altitude Tsaratanana rainforest, and to the north by dry forests, but, to the south is not isolated from rainforest of similar altitude in the East Region. The East rainforest is bordered to the north by the rainforest of the Northeast, west by high altitude rainforest of the High Plateau, but the southern border remains unknown at present (although other herpetological species distributions suggest a southern limit in the southeastern region between latitude 22 and $24^{\circ} \mathrm{S}$ ).

Table IV presents the Brookesia distribution for each endemic region. Each endemic centre has 2-6 Brookesia species, of which 1-3 species are regionally endemic, giving 50-75\% endemicity. 


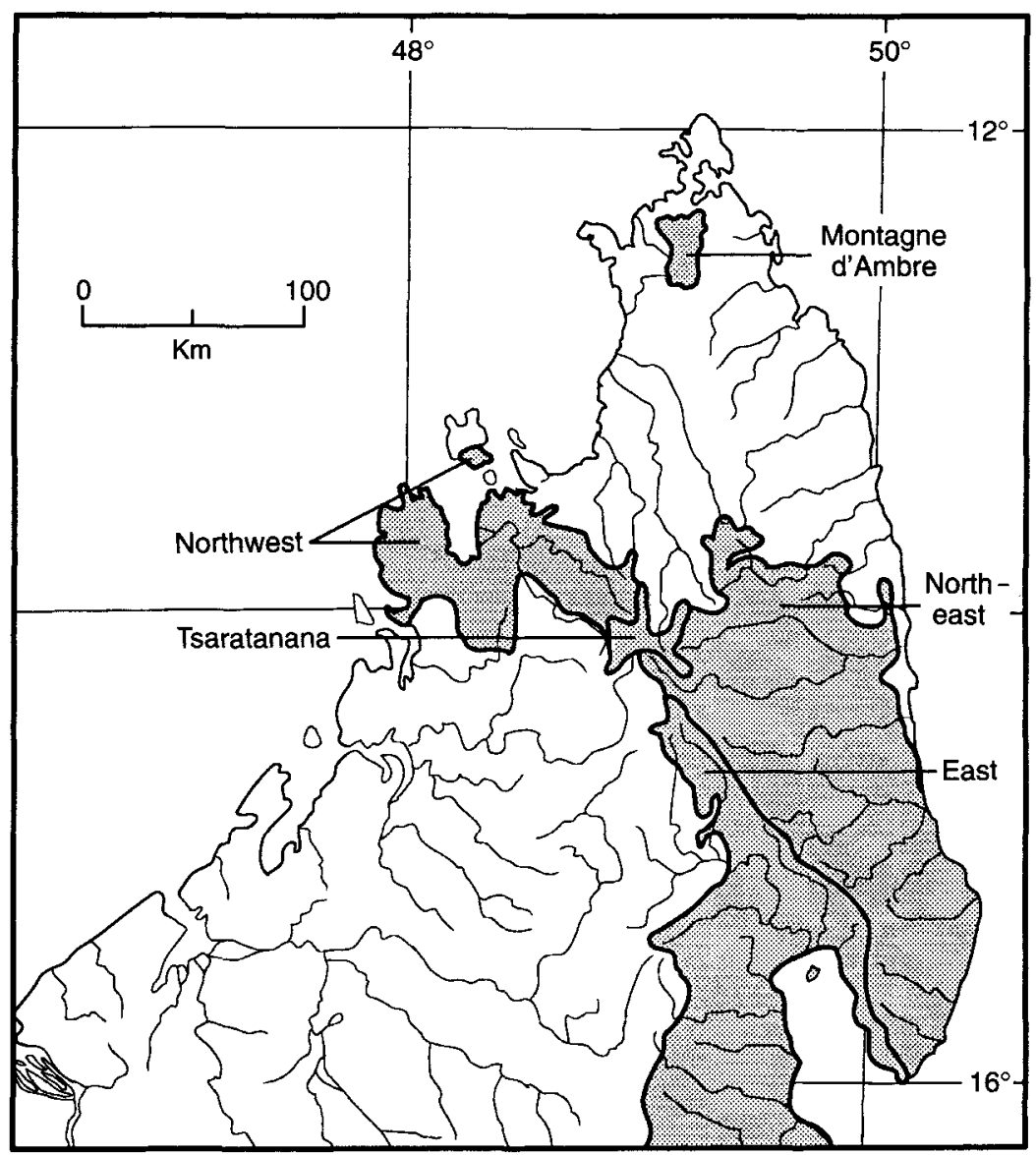

FIG. 7. Proposed biogeographical regions for the northern rainforest.

Three species (Brookesia ebenaui, B. minima and B. stumpffi) are shared between the Montagne d'Ambre and Northwest Regions, indicating a close similarity between the two faunas.

The Northeast Region presents a problem in that it is not clearly isolated from the East Region. Brookesia karchei and B. griveaudi are both endemic to the Northeast Region, being absent from rainforest in the Antongil Bay watershed and further south on the eastern escarpment. Brookesia superciliaris, B. thieli and B. vadoni appear to have their northern distribution limits confined to the Antongil Bay watershed. Based on these data, we consider the southwestern limit of the Northeast Region to be the Antongil-Indian Ocean watershed, although new data may require modification of this boundary.

Based on the distribution of regional endemics, we propose the following new biogeographic divisions of the northern rainforests of Madagascar (Fig. 7).

(1) Montagne d'Ambre Region. Rainforest between 400 and $1475 \mathrm{~m}$ altitude of the Montagne d'Ambre mountain range.

(2) Tsaratanana Region. Rainforest above $1200 \mathrm{~m}$ altitude of the Tsaratanana Mountain range. 
TABLE IV

Species distributions in the five rainforest biogeographic regions of northern Madagascar

\begin{tabular}{|c|c|c|c|c|c|}
\hline \multirow[b]{2}{*}{ SPECIES } & \multicolumn{5}{|c|}{ REGION } \\
\hline & Ambre & Northwest & Tsaratanana & Northeast & East \\
\hline \multicolumn{6}{|l|}{ Regional endemics } \\
\hline Brookesia ambreensis sp. nov. & * & & & & \\
\hline B. antakarana sp. nov. & * & & & & \\
\hline B. bekolosy sp. nov. & & * & & & \\
\hline B. lineata sp. nov. & & * & & & \\
\hline B. valerieae & & * & & & \\
\hline B. lolontany sp. nov. & & & * & & \\
\hline B. griveaudi & & & & * & \\
\hline B. karchei & & & & * & \\
\hline B. superciliaris & & & & & * \\
\hline B. thieli & & & & & * \\
\hline B. vadoni & & & & & $*$ \\
\hline Non-regional endemics & & & & & \\
\hline Brookesia ebenaui & * & * & & & \\
\hline B. stumpffi & * & * & & & \\
\hline B. betschi & & & * & * & \\
\hline B. minima & * & * & & * & \\
\hline
\end{tabular}

(3) Northwest Region. Rainforest between 0 and $1876 \mathrm{~m}$ altitude west of the Tsaratanana Region.

(4) Northeast Region. Rainforest between 0 and $2133 \mathrm{~m}$ altitude east of the Tsaratanana Region and Antongil Bay-Indian Ocean watershed.

(5) East Region. Rainforest between 0 and $2064 \mathrm{~m}$ altitude west of the Antongil Bay-Indian Ocean watershed and east of the High Plateau. The southern limit has not yet been determined.

This biogeographic division of the northern rainforest differs from previous authors in that both Montagne d'Ambre and Tsaratanana are recognized as discrete biogeographic regions. The Northwest Region is similar to the Sambirano Domain of Humbert (1955) and Koechlin (1972) except that rainforest above $800 \mathrm{~m}$ is included. The Northeast Region has previously been treated as part of the Eastern Domain.

Preliminary studies, using other herpetological groups (e.g. Amphiglossus, Liopholidophis, Mantidactylus, Plethodontohyla) also suggest these new biogeographical regions represent centres of endemicity. If these centres of endemicity have been accurately identified, we expect them to be supported by distribution data from other groups which are restricted to rainforest.

\section{Speciation}

Twelve species of Brookesia, representing just over half the total Brookesia species, are restricted to northern Madagascar. Speciation has obviously been prolific in this region, almost certainly because of the fragmented pattern of the different rainforest types. The current isolation of the Montagne d'Ambre rainforest, which is now separated by $110 \mathrm{~km}$ of dry habitat from the closest rainforests to the south, probably facilitated vicariant speciation. Brookesia ambreensis, a Montagne d'Ambre endemic, appears to be the sister species of $B$. valerieae a species restricted to the Northwest. The occurrence of Brookesia ebenaui and B. minima (both 
obligate rainforest specialists) at both Montagne d'Ambre and the Northwest demonstrated these populations must have once been continuous. Connecting corridors of rainforest between Montagne d'Ambre and the Northwest would have been largely composed of low altitude rainforest because of the low relief in the area. Isolation, therefore, has been less severe for the low altitude specialists Brookesia ebenaui and B. minima, compared to the mid-latitude specialists $B$. ambreensis and B. antakarana. The endemic Brookesia of Montagne d'Ambre are both midaltitude specialists; none of the low altitude species is endemic to Montagne d'Ambre.

The Tsaratanana Mountain range forms a barrier of high altitude rainforest above $1500 \mathrm{~m}$ that cuts across the east-west northern rainforest belt. The low and mid-altitude species are isolated either east or west of this mountain range. Only high altitude species occur within the Tsaratanana Mountains. Vicariance is again evident, with Brookesia nasus, the probable sister species of the Tsaratanana endemic B. lolontany, found at high altitudes in the mountains of the southeast.

The Tsaratanana barrier is so effective that only one species, Brookesia minima, actually occurs both east and west of the mountains. Brookesia stumpffi and B. griveaudi are phenetically very similar, and are almost certainly sister species. They are completely allopatric, found either to the east (B. stumpff) or west (B. griveaudi) of the Tsaratanana Mountains. The Tsaratanana Mountains may have divided previously widespread Brookesia populations as a result of a change in climate. Low or mid-altitude rainforest may once have formed an east-west corridor to the north and/or south of the Tsaratanana Mountains, which has subsequently been lost due to a contraction of the rainforest belt in response to climatic change.

There has been surprisingly little discussion regarding changes in Malagasy vegetation in response to global climatic changes. This is probably due to earlier concepts of Madagascar being completely covered in forest prior to the arrival of man (e.g. Perrier de la Bathie, 1936; Humbert, 1955), and the inference of vegetational stability before human colonization.

Recently Burney \& MacPhee (1988) reported palynological evidence demonstrating significant vegetational changes in Madagascar over the last 11,000 years. At Lake Tritrivakely, on the High Plateau, they found the vegetation changed from heathshrub to grassland to trees and shrubs between 11,000 and 4,000 BP. They suggested these changes were most likely caused by climatic change. These changes in vegetation considerably pre-date human colonization, which is considered to have begun about 1,500 BP (see Dewar, 1984). Burney (1987: 141) noted that "climatic cycles of the glacial and interglacial intervals could prove to be as significant in explaining vegetational and evolutionary patterns in Madagascar as they have elsewhere in the tropics".

In East Africa, palynological evidence demonstrates both significant expansion and contraction of rainforest during the late Pleistocene Period, which is thought to have been produced by climatic changes, especially regarding precipitation (Coe, 1989; Roche \& Bikwemu, 1989). The climatic changes of the Pleistocene were global, and undoubtedly must have affected the distribution of all vegetation types in Madagascar.

Rainforest was probably much more widespread in Madagascar during interglacial periods of the Pleistocene when the climate was wetter. In northern Madagascar, the vicariant patterns found in Brookesia suggest that rainforest once linked Montagne d'Ambre with the rainforests of the Northwest, and formed low altitude rainforest corridors to the north and south of Tsaratanana. Climatic changes may also be responsible for the high degree of regional endemicity found in the northern rainforests. Low precipitation, typical for the glacial maxima of the Pleistocene, would have caused contraction of rainforest into small refugia within the 
complex mountain systems of northern Madagascar. Brookesia populations would also have been isolated within different rainforest refugia, and this fragmentation may have facilitated considerable allopatric speciation in northern Madagascar.

We thank J.B. Ramanamanjato, A. Raselimanana, and Angeluc and Angelin Razafimanantsoa for their considerable help during the fieldwork associated with this study. We thank D. Bay for photographic assistance and M. Van Bolt for drawing the Figures. We thank the Ministère de l'Enseignement Supérieur, the Ministère de la Production Animale et des Eaux et Forêts and the Ministère de la Research Scientifique et Technologie pour le Developpement whose support made this research program possible. This research was supported in part by a grant from the National Science Foundation (BSR-90-24505), World Wide Fund for Nature, CARE and Earthwatch.

\section{REFERENCES}

Angel, F. (1942). Les lézards de Madagascar. Mém. Acad. malgache 36: 1-193.

Boettger, O. (1880). Diagnosis reptilium et batrachiorum novorum a Caroloa Ebenau in insula Nossi-Bé Madagascariensi lectorum. Zool. Anz. 3: 279-283.

Boettger, O. (1881). Die Reptilien und Amphibien von Madagascar. Dritter Nachtrag. Abh. senckenb. naturforsch. Ges. 12: $435-558$.

Boettger, O. (1893). Katalog der Reptilien-Sammlung im Museum der Senckenbergischen Naturforschenden Gesellschaft in Frankfurt am Main. I. Frankfurt am Main: Druck von Gebrüder Knauer.

Brygoo, E. R. (1978). Reptiles sauriens chamaeleontidae. Genre Brookesia et complément pour le genre Chamaeleo. Faune Madagascar 47: 1-173.

Brygoo, E. R. \& Domergue, C. A. (1969). Un Brookesia des forêt orientales de Madagascar, $B$. thieli n. sp. (Chamaeléonidés). Bull. Mus. natn. Hist. nat. Paris. 40: 1103-1109.

Brygoo, E. R. \& Domergue, C. A. (1970). Notes sur les Brookesia de Madagascar. IV. Une Série de petits Brookesia de Nosy Mangabé (Chamaeléonidés). Bull. Mus, natn. Hist. nat. Paris. 41: 833-841.

Brygoo, E. R. \& Domergue, C. A. (1971). Notes sur les Broakesia (Chamaeléonidés) de Madagascar. Description d'une espèce nouvelle, $B$. antoetrae n.sp., et des hémipénis de $B$. stumpffi and $B$. ebenaui. Remarques sur la répartition de B. stumpffi. Bull. Mus, natn. Hist. nat. Paris. 42: 830-838.

Brygoo, E. R. \& Domergue, C. A. (1975). Notes sur les Brookesia de Madagascar, XI. Observations sur B. tuberculata Mocquard, 1894, B. ramanantsoai sp. nov. et B. peyrierasi nom nov. (Reptilia, Squamata, Chamaeleontidae). Bull. Mus. natn. Hist. nat. Paris (Zool.) 267: 1769-1782.

Burney, D. A. (1987). Late Holocene Vegetational Change in Central Madagascar. Quat. Res., Tokyo $28: 130-143$.

Burney, D. A. \& MacPhee, R. D. E. (1988). Mysterious island. What killed Madagascar's large native animals? Nat. Hist. 97 (7): 47-54.

Coe, M. (1989). Biogeographical affinities of the high mountains of tropical Africa. In Quaternary and environmental research on East African mountains: 257-278. Mahaney, W.C. (Ed.). Rotterdam: A.A. Balkema.

Dewar, R. E. (1984). Recent extinctions in Madagascar: The loss of the subfossil fauna. In Quaternary extinctions: A prehistoric revolution: 574-593. Martin, P.S. \& Klein, R.G. (Eds). Tuscon: University of Arizona Press.

Fitzinger, L. (1843). Systema Reptilium. Fasciculus primus.Vindobonae: Braumüller et Seidel Bibliopolas.

Gray, J. E. (1865). Revision of the genera and species of the Chamaeleonidae, with the descriptions of some new species. Proc. zool. Soc. Lond. 1864: 465-477.

Guillaumet, J.-L., Betch, J.-M., Blanc, C., Morat, P. \& Peyrieras, A. (1975). Étude des écosystèmes montagnards dans la région malgache. 3. Le Marojezy. 4. L'Itremo et L'Ibity. Géomorphologie, climatologie, faune et flore (Campagne RCP 225, 1972-3). Bull. Mus. natn. Hist. nat. Paris (Écol. gen.) No. 309: 29-67.

Günther, A. (1874). Descriptions of some new or imperfectly known species of reptiles from the Cameroon Mountains. Proc. zool. Soc. Lond. 1874: 442--445.

Humbert, H. (1955). Les Territoires Phytogéographiques de Madagascar, leur cartographie. Ann. Biol. 31 : $195-204$.

Keller, C. (1901). Madagascar, Mauritius and the other East-African islands. London: Swan Sonnenschein.

Klaver, C. \& Böhme, W. (1986). Phylogeny and classification of the Chamaeleontidae (Sauria) with special reference to hemipenis morphology. Bonn. zool. Monogr No. 22: 1-64.

Koechlin, J. (1972). Flora and vegetation of Madagascar. In Biogeography and ecology of Madagascar: $145-190$. Battistini, R. \& Richard-Vindard, G. (Eds). The Hague: Junk. 
Kuhl, H. (1820). Beiträge zur Zoologie und vergleichenden Anatomie. Erste Abtheilung. Beitrage zur Zoologie. Frankfurt am Main: Hermannschen Buchandlung.

Perrier de la Bathie, H. (1936). Biogéographie des Plantes de Madagascar. Paris: Société d'Editions Géographiques, Maritimes, et Coloniales.

Mocquard, F. (1894). Reptiles nouveaux ou insuffisamment connus de Madagascar. C. r. somm. Séanc. Soc. Philom. Paris. No. 17: 3-10.

Mocquard, F. (1900). Diagnose d'espèces nouvelles de Reptiles de Madagascar. Bull. Mus. natn. Hist. nat. Paris 6: 345-8. Mocquard, F. (1909). Synopsis des familles, genres et espèces des Reptiles éscailleux et des Batraciens de Madagascar. Nouv. Archs Mus. Hist. nat., Paris (5) 1: 1-110.

Ramanantsoa, G. A. (1979). Description de deux nouvelles espèces de Brookesia (Reptilia, Squamata, Chamaleontidae): B. legendrei et B. bonsi. Bull. Mus. natn. Hist. nat. Paris (Zool.) No. 3: 685-693.

Raxworthy, C. J. (1991). Field observations of some dwarf chameleons (Brookesia spp.) from rainforest areas of Madagascar, with the description of a new species. J. Zool., Lond. 224: 11-25.

Roche, E. \& Bikwemu, G. (1989). Paleoenvironmental change on the Zaire-Nile ridge in Burundi; the last 20,000 years: An interpretation of palynological data from the Kashiru Core, Ijenda, Burundi. In Quaternary and environmental research on East African mountains: 231-242. Mahaney, W.C. (Ed.). Rotterdam: A.A. Balkema.

Werner, F. (1902). Prodromus einer Monographie der Chamäleonten. Zool. Jb. (Syst.) 15: 295-460. 